UNIVERSIDADE DE BRASÍLIA - UnB

CENTRO DE EXCELÊNCIA EM TURISMO - CET

CURSO DE ECOTURISMO

\title{
ROTEIRO ECOTURÍSTICO DE CURTA DURAÇÃO NO DISTRITO FEDERAL E ENTORNO (MONOGRAFIA)
}

\author{
POR: \\ RICARDO DE ALBUQUERQUE ASSIS REPUBLICANO \\ Matrícula: 04/001653
}

Brasília (DF)

2004 
RICARDO DE ALBUQUERQUE ASSIS REPUBLICANO

ROTEIRO ECOTURÍSTICO

DE CURTA DURAÇÃO NO DISTRITO FEDERAL E ENTORNO

(MONOGRAFIA)

Monografia de conclusão do Curso de Pós-Graduação em Ecoturismo no Centro de Excelência em Turismo, da Universidade de Brasília (UnB).

Orientadora: Prof $^{a}$. Dr ${ }^{a}$ Lourdes Bandeira.

Brasília (DF)

2004 
"Get up, stand up / Stand up for your rights. Get up, stand up / Don't give up the fight”.

(Bob Marley) 


\section{AGRADECIMENTOS}

À Universidade de Brasília, pela oportunidade de crescer, oferecida a milhares de estudantes; pela sua história em prol das lutas sociais; pela indiscutível qualidade do ensino.

À Professora Orientadora, Doutora LOURDES BANDEIRA, pela paciência, atenção e dedicação pelo qual me acompanhou, sem medir esforços, sempre incentivando nos momentos difíceis.

Aos colegas de curso que, de alguma forma, incentivaram, animando-me e se colocando minha à inteira disposição.

A todos, meu sincero MUITO OBRIGADO!

Ricardo de Albuquerque Assis Republicano 


\section{DEDICATÓRIA}

A meus pais, JADER e IRMA REPUBLICANO, que sempre me incentivaram, bem como pelo carinho e compreensão em mais esta etapa. 


\section{SUMÁRIO}

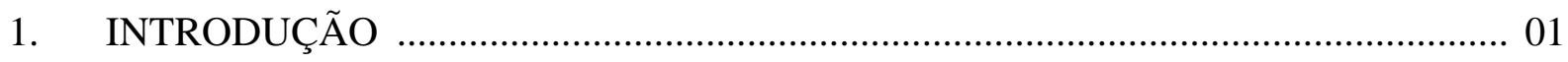

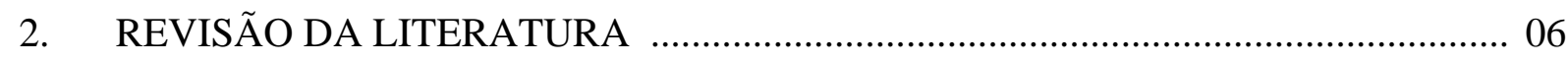

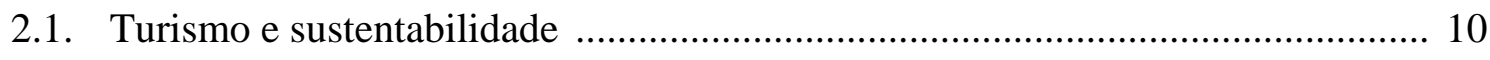

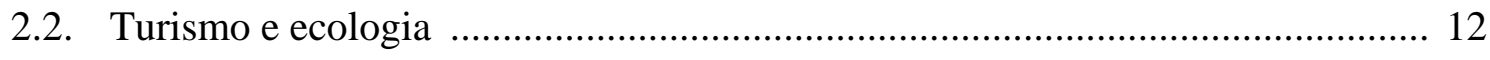

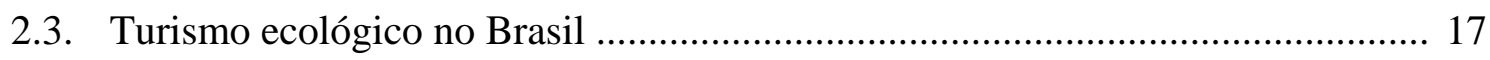

3. PERFIL DO EMPREENDIMENTO DE ECOTURISMO ...................................... 31

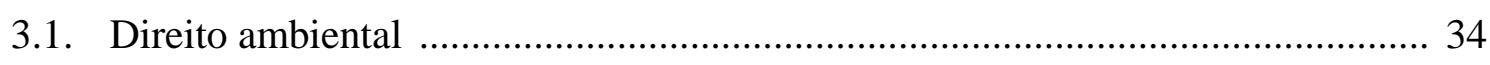

4. PERFIL DO TURISMO NO DISTRITO FEDERAL …......................................... 42

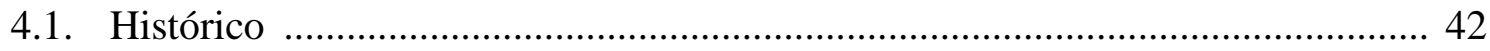

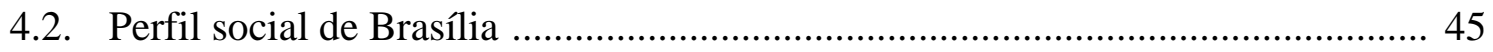

4.3. Perfil turístico de Brasília ............................................................................ 48

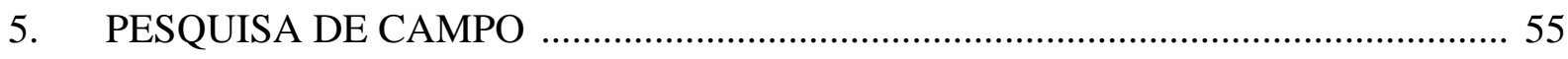

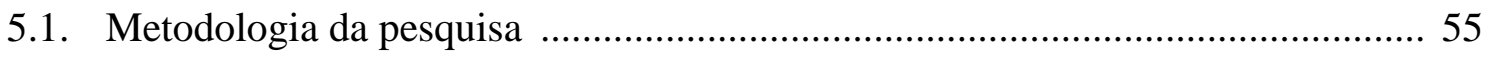

5.2. Apresentação dos dados da pesquisa .............................................................. 59

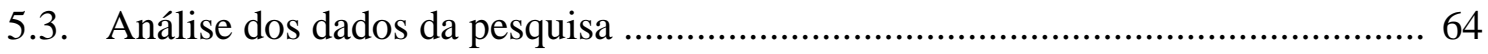

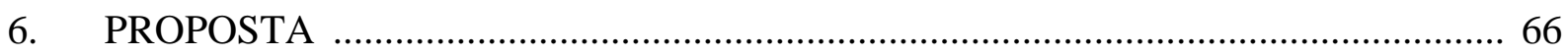

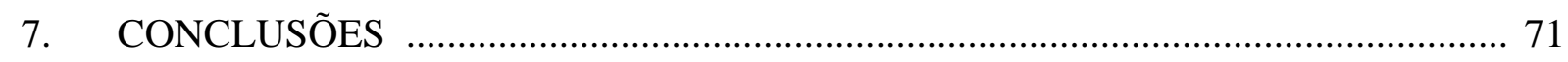

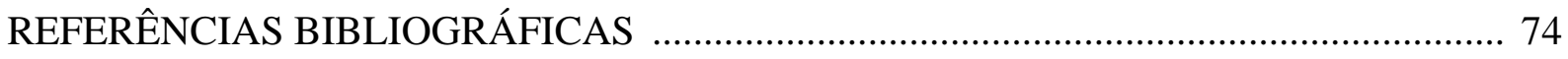

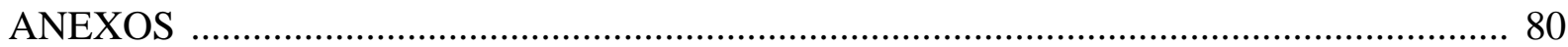

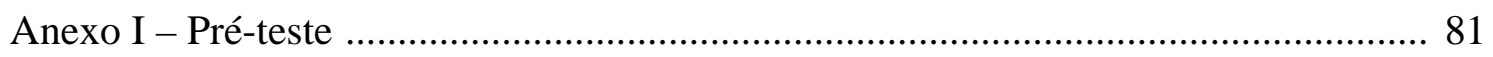

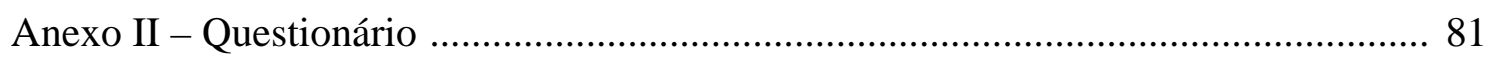




\section{LISTA DE TABELAS}

Tabela 1. Brasília - Quanto à freqüência de hóspedes que permanecem em Brasília por prazo igual ou inferior a dois dias - 2004

Tabela 2. Brasília - Quanto à freqüência de hóspedes que buscam programação turística alternativa - 2004 60

Tabela 3. Brasília - Quanto à freqüência de hóspedes que procuram programação turística de curta duração (máximo 2 dias) - 2004

Tabela 4. Brasília - Quanto à freqüência de hóspedes que procuram atividades turísticas direcionadas à ecologia - 2004 62

Tabela 5. Brasília - Quanto à freqüência de hóspedes que buscam programação turística voltada para a Região do Entorno do DF - 2004 


\section{LISTA DE GRÁFICOS}

Gráfico 1. Brasília - Quanto à freqüência de hóspedes que permanecem em Brasília por prazo igual ou inferior a dois dias - 2004

Gráfico 2. Brasília - Quanto à freqüência de hóspedes que buscam programação turística alternativa - 2004 60

Gráfico 3. Brasília - Quanto à freqüência de hóspedes que procuram programação turística de curta duração (máximo 2 dias) - 2004 61

Gráfico 4. Brasília - Quanto à freqüência de hóspedes que procuram atividades turísticas direcionadas à ecologia - 2004 62

Gráfico 5. Brasília - Quanto à freqüência de hóspedes que buscam programação turística voltada para a Região do Entorno do DF - 2004 63 


\section{LISTA DE SIGLAS}

AIEST - Associação Internacional de Especialistas na Ciência do Turismo.

CF - Constituição Federal.

CMMAD - Comissão Mundial sobre Meio Ambiente e Desenvolvimento.

CMVT - Conselho Mundial de Viagens e Turismo.

DF - Distrito Federal.

DR - Doutor.

EMBRATUR - Empresa Brasileira de Turismo.

FIBRA - Federação das Indústrias de Brasília.

IBAMA - Instituto Brasileiro do Meio Ambiente.

JK - Juscelino Kubitschek.

KM - Quilômetro.

LBV - Legião da Boa Vontade.

MMA - Ministério do Meio ambiente.

MS - Microsoft.

OCE - Oficinas de Capacitação em Ecoturismo.

OMT - Organização Mundial do Turismo.

ONG - Organização Não-Governamental.

ONU - Organização das Nações Unidas.

PF - Polícia Florestal.

SEMATEC - Secretaria de Meio Ambiente, Ciência e Tecnologia.

SETUR - Secretaria de Turismo.

UAIT - União Árabe Internacional de Turismo.

UC - Unidades de Conservação.

UNESCO - Organização das Nações Unidas para a Educação, a Ciência e a Cultura. 


\section{RESUMO}

Este trabalho, que estudou a possibilidade de criação de roteiro ecoturístico de curta duração destinado ao visitante (individual ou em pequenos grupos), limitou-se ao espaço do Distrito Federal e à Região do Entorno. Considerando-se o ângulo do turismo, como segmento econômico e campo de estudo, este trabalho se baseia na necessidade de se manter abertos a pesquisa e o debate acerca das inúmeras formas de se promover o maior desenvolvimento do ecoturismo local. Assim, buscou-se adequar, ao máximo, as atividades paralelas e complementares à atividade ecoturística, de modo a aumentar a gama de opções para o turista que visita a Capital Federal e que dispõe de pouco tempo livre. 


\begin{abstract}
This work studies the possibility of creating a short period ecotouristic route destined to the visitor (individual or in small groups), in the Distrito Federal (Federal District) and surrounding region. Considering tourism as an economic segment and field of study, this work is based on the necessity of keeping opened the research and the debate concerning different ways to promote a greater development of the local ecotourism. Thus, the complementary and parallel activities were adjusted to the ecotouristic activity, in order to increase the number of options for the tourist who visits the capital city of Brazil, and has little free time..
\end{abstract}




\section{INTRODUÇÃO}

A questão ambiental não envolve apenas a natureza, mas também o direito humano de dispor de qualidade de vida. Com a Revolução Industrial, que levou o mundo às transformações econômicas e sociais através dos avanços tecnológicos, os recursos naturais têm sido utilizados em larga escala, o que vem causando danos ao meio ambiente. Constatou-se que era necessário um novo modelo de desenvolvimento que visasse uma política global de sustentabilidade, em que a conservação do meio ambiente estivesse intimamente relacionada com a eficiência econômica e a justiça social. Ou seja, um desenvolvimento que associasse a proteção ambiental às políticas de desenvolvimento, diferente do desenvolvimento predatório visto até então ${ }^{1}$.

No plano internacional, o turismo é considerado uma das atividades econômicas de maior importância. O mercado turístico tem como seus principais agentes econômicos: os consumidores, que têm como objetivo aumentar suas satisfações e as empresas que buscam aumentar seus lucros. O turismo, que já foi entendimento apenas como atividade de viagem, no século XXI passou a ser atividade socioeconômica, pois gera bens e serviços, sendo atividade descentralizada que pode ser organizada em cada município ou região, podendo gerar divisas, criar empregos, distribuir renda e aumentar a qualidade de vida da população ${ }^{2}$.

O turismo é considerado um sistema integrado (governo, agências de viagens, empresas de transporte, sistema hoteleiro, bares, restaurantes, entre outros) que, sem a conscientização de todos, torna-se predatório. Por isso é necessário um "planejamento que vise a definição dos objetivos, um inventário dos recursos naturais e culturais, análise da situação, com planos de longo prazo e projetos estratégicos”3. Já o ecoturismo é o segmento do turismo que possibilita a eficiência na atividade econômica mantendo a diversidade e estabilidade do meio ambiente, tendo como base o modelo sustentável, podendo atuar como instrumento de sensibilização, orientação e equilíbrio

\footnotetext{
${ }^{1}$ PELEGRINI FILHO, Américo. Ecologia, cultura e turismo. 6. ed. Campinas (SP): Papirus, 2001, p. 15.

${ }^{2}$ Idem, p. 16.

${ }^{3}$ OLIVEIRA, A. Turismo e desenvolvimento. Florianópolis (SC): Terceiro Milênio, 1998, p. 23.
} 
entre os desgastes causados pelo desenvolvimento econômico e a necessidade de preservar o patrimônio natural e cultural de uma região.

O ecoturismo não pode ser considerado turismo ideal, que não causa impactos e que não polui, mas se for comparado a outras atividades, é o que menos prejudica o meio ambiente. Porém, pode ser praticado de maneira racional, duradoura e capaz de melhorar a qualidade de vida de uma grande parcela da população. É o Ecoturismo responsável, que se aproxima da sustentabilidade, visando à conservação do patrimônio natural e cultural, desenvolvendo atividades lucrativas que possam garantir a sua manutenção e a melhoria de vida das comunidades envolvidas ${ }^{4}$.

Em função de sua estrutura, complexidade e heterogeneidade, a oferta turística resulta na composição de um conjunto de atividades, tanto econômicas como sociais e culturais. Ela compreende os atrativos em geral, como os recursos naturais, históricos e culturais; infra-estrutura em geral como meios de hospedagem; alimentação; transporte; entretenimento; serviços de apoio ao turista e outros. É a quantidade de bens e serviços consumidos pelos visitantes que caracteriza a demanda turística. Além da qualidade das destinações turísticas e da infra-estrutura oferecida ao visitante, a originalidade do lugar está sendo sempre avaliada. A essência do ecoturismo está em oferecer ao turista experiência rica e autêntica de vivência junto a ecossistemas. Associadas a isso, são oferecidas condições de conforto, recreação, disponibilidade de equipamentos turísticos característicos e diferenciados, além do importante incentivo às práticas conservacionistas dos empreendimentos ${ }^{5}$.

Diante do exposto, este estudo que visa estudar a possibilidade de criação e implantação de um roteiro ecoturístico de curta duração destinado ao indivíduo (pessoa e pequenos grupos), limitando-se geograficamente ao espaço do Distrito Federal e à Região do Entorno. Deste modo, o trabalho encontra as seguintes justificativas para sua realização:

\footnotetext{
${ }^{4}$ LINDBERG, Kreg \& HAWKINS, Donald E. Ecoturismo - um guia para planejamento e gestão. 4. ed. São Paulo: SENAC, 2002, p. 13.

${ }^{5}$ ANDRADE, José V. Turismo - fundamentos e dimensões. São Paulo: Ática, 1992, p. 106.
} 
a) primeiro, do ponto de vista pessoal, o estudo se justifica por se constituir oportunidade ímpar de, ainda em âmbito acadêmico, desenvolver trabalho que reúna, em si mesmo, teoria e prática;

b) considerando-se o ângulo do turismo, como segmento econômico e, também, como campo de estudo, a justificativa para a realização deste trabalho pode ser explicada pela necessidade de se manter abertos a pesquisa e o debate acerca das inúmeras formas de se promover o maior desenvolvimento do ecoturismo local. Buscase adequar, ao máximo, as atividades paralelas e complementares à atividade ecoturística, para que esta adquira o máximo possível de resultados financeiros para a região. Procurando, no caso de Brasília, não permitir a degradação do meio ambiente, mas que, ao contrário, sirva, também, para a divulgação dos ideais de desenvolvimento sustentável;

c) pelo lado social, a justificativa reside no fato de que é importante se buscar formas diversificadas e complementares de dinamizar este segmento (um dos que mais se desenvolvem nos tempos atuais), o qual tende a ser um dos principais geradores de emprego e renda nesse século que se inicia;

d) finalmente, levando-se em conta a pouca oferta de roteiros ecoturísticos de curta duração voltados para pequenos grupos (de até 4 pessoas), e constatando crescente interesse para tal segmento, vê-se a necessidade de criar formas alternativas para incrementar a pouca demanda existente.

Neste estudo, as questões-problema propostas podem ser assim apresentadas:

a) o mercado turístico de Brasília comporta inovações, tais como as modalidades mais modernas de turismo (turismo de aventura, turismo ecológico, entre outros), ou seria, em sua maior parte, um mercado conservador (turismo de eventos, turismo de lazer), ou seja, aquele em que predomina o consumo dos produtos tradicionais (tais como turismo de negócios ou de eventos)? 
b) há, em Brasília, um público significativo para um roteiro ecoturístico voltado para o consumidor individual, ou de pequenos grupos (de, no máximo, quatro pessoas), e que tenham pouca disponibilidade de tempo? Ou, ainda: que tipo de demanda esse público almeja?

c) é possível combinar, a inserção, no mercado de Brasília ou na região do entorno, de um roteiro ecoturístico de curta duração (de no máximo dois dias) voltado ao consumidor individual ou de pequenos grupos, que, ao mesmo tempo, não se converta em ação devastadora do patrimônio e do ecossistema locais, mas que, ao contrário, se converta em compromisso de desenvolvimento sustentável, em que se busque a preservação do meio ambiente?

Com este objetivo geral, pretendeu-se analisar a viabilidade de se inserir, no mercado de Brasília, um roteiro ecoturístico de curta duração individual, ou para pequenos grupos (de, no máximo, 4 pessoas), visto que há pouca oferta desse tipo na cidade, nas opções que serão apresentadas adiante.

Como objetivos específicos, buscou-se:

a) identificar, com base na literatura, os principais conceitos e premissas que sirvam para definir roteiros ecoturísticos;

b) desenvolver levantamento junto à recepção e às agências de viagens localizadas nos hotéis, visando avaliar a viabilidade de se inserir, no mercado de Brasília, um roteiro ecoturístico de curta duração individual ou de pequenos grupos;

c) desenvolver roteiro ecoturístico de curta duração individual para visitantes (ou pequenos grupos), direcionado ao seleto mercado de turismo de Brasília e que atenda as expectativas dos turistas.

Para tanto, foram estudadas as variáveis: “tempo de permanência do turista”, 
“demanda por turismo alternativo”, “duração do programa turístico”, “demanda por ecoturismo”, e “demanda por atividades na Região do Entorno do DF”, variáveis essas cujas análises serviram de embasamento para a estruturação dos roteiros que serão apresentados ao final desse estudo.

Na realização do trabalho foram adotados dois procedimentos metodológicos básicos, quais sejam:

a) pesquisa de cunho bibliográfico, por meio da qual se buscou conhecer as premissas e os conceitos que melhor auxiliem no entendimento do tema;

b) pesquisa de campo, desenvolvida junto ao conjunto de estabelecimentos diretamente relacionados à atividade turística de Brasília (agências turísticas e recepções de hotéis), em que se distribuiu questionários (em anexo), no intuito de conhecer a opinião de visitantes e de profissionais da área, a respeito da possibilidade de se inserir, no mercado de Brasília, um roteiro ecoturístico de curta duração individual ou para pequenos grupos (de, no máximo, cinco pessoas).

Portanto, tendo sido explicadas aqui as diretrizes gerais deste trabalho, passa-se agora ao seu desenvolvimento, iniciando com a revisão da literatura, por meio da qual serão expostas as opiniões e conceitos dos autores consultados acerca do turismo, enfatizando-se seus aspectos históricos, de sustentabilidade e legislação vigente.

${ }^{6} \mathrm{O}$ "turismo alternativo" aqui considerado é aquele que oferece, ao turista, formas pouco usuais de diversão, tais como o turismo de aventura (vôo livre, montanhismo, alpinismo, entre outros), turismo místico-religioso (festas religiosas, igrejas, romarias, entre outros), turismo ecológicos (visitação a parques, cavernas, jardins botânicos e zoológicos, reservas florestais), turismo de pesquisa (visitas a museus, observatórios espaciais, entre outros). Contrariamente, o "turismo convencional" seria, então, aquele que oferece, ao turista, passeios relacionados a atividades comerciais mais comuns, tais como boites, "city tour", praias populares, construções arquitetônicas em meio à cidade. Assim, no caso desse trabalho, em relação à Brasília e sua Região do Entorno, o que se chama de "turismo alternativo" é aquele cujas opções de passeio não levam a lugares tais como Catedral, Palácios variados, Terceira Ponte do Lago, Torre de Televisão, Teatro Nacional, nem às casas noturnas ou demais opções de diversões próprias do meio urbano. 


\section{REVISÃO DA LITERATURA}

A partir de 1960, o turismo transformou-se em uma atividade de grande porte em termos econômicos, sociais e culturais, tendo início o turismo de massa ${ }^{7}$. Em 1960 explode com as possibilidades do lazer e, portanto como fonte de lucros e investimentos. Essa evolução dos acontecimentos econômicos e sociais do mundo moderno transformou o turismo em setor bastante promissor, sendo uma atividade que atende a demanda do lazer e mobiliza enorme volume de recursos. É atividade econômica, geradora de riqueza, estando o seu desempenho relacionado ao comportamento da renda, sua distribuição e ao tempo livre disponível.

O turismo se integra na política de valorização do bem-estar, através da conservação dos recursos naturais e a melhoria dos recursos humanos. O turismo no mercado profissional traz melhorias na qualidade, produtividade e na remuneração dos trabalhadores, mas são necessários estudos e ações para que verdadeiramente produza benefícios sociais.

O Instituto Brasileiro de Turismo (EMBRATUR) ${ }^{8}$ foi criado em 1966 e tem como competências, entre outras: a) propor ao Governo Federal normas e medidas necessárias à execução da Política Nacional de Turismo e executar as decisões que, para esse fim, lhe sejam recomendadas; b) inventariar, hierarquizar e ordenar o uso e ocupação de áreas e locais de interesse turístico e estimular o aproveitamento dos recursos naturais e culturais que integram o patrimônio turístico, com vistas à sua preservação; c) estimular as iniciativas destinadas a preservar o ambiente natural e a fisionomia social e cultural dos locais turísticos e das populações afetadas pelo seu desenvolvimento.

A Associação Internacional de Especialistas na Ciência do Turismo (AIEST) adotou a seguinte definição:

\footnotetext{
${ }^{7}$ Turismo que, em função dos preços reduzidos decorrentes dos chamados “pacotes, torna-se viável a uma gama cada vez maior de pessoas.

${ }^{8}$ EMBRATUR. Diretrizes para uma política nacional de ecoturismo. Brasília: EMBRATUR, 1994, p. 29.
} 
“o turismo é o conjunto das relações e dos fenômenos produzidos pelo deslocamento e permanência de pessoas fora do seu local de domicílio, sempre que ditos deslocamentos e permanências não estejam motivados por uma atividade lucrativa”. ${ }^{9}$

A Organização Mundial do Turismo $(\mathrm{OMT})^{10}$ definiu como sendo "a soma das relações e de serviços resultantes de um cambio de residência temporário e voluntário motivado por razões alheias a negócios”.

O Consultor de Turismo da Organização Internacional do Trabalho (1971) e Presidente eleito da União Árabe Internacional de Turismo (UAIT - 1972), SALAHELDIN ABDEL WAHAB, definiu o turismo como:

"Uma atividade humana intencional que serve como meio de comunicação e como elo de interação entre povos, tanto dentro como fora de um país. Envolve deslocamento temporário de pessoas para outras regiões ou países visando a satisfação de outras necessidades que não a de atividade remuneradas". ${ }^{11}$

A relação turismo e meio ambiente merece destaque, já que o turismo pode gerar efeitos desastrosos ao meio ambiente, caso não seja adequadamente dimensionado. A década de 1970 marcou o início da preocupação com o meio ambiente dando ênfase à ameaça aos recursos naturais e perda de lucro que a degradação provoca, passando o turismo a ser instrumento de preservação.

Entre os segmentos do turismo pode-se destacar ${ }^{12}$ :

- Turismo Ambiental que visa o estudo do meio, e pode ser praticado nos mais diversos tipos de destinos, sejam eles urbanos ou rurais;

- Turismo Rural é uma vivência no ambiente de fazendas ou outras

\footnotetext{
9 BARRETO, Margarita. Manual de iniciação ao estudo do turismo. Campinas - São Paulo: Papirus, 1995, p. 11.

10 OMT, Organização Mundial de Turismo. Dados e tendências mundiais. < http://www.worldtourism.org >. Acesso em 05.set.2003.

${ }^{11}$ TRIGO, Op. Cit., p.10.

12 ANDRADE, José V. Turismo - fundamentos e dimensões. São Paulo: Ática, 1992, pp. 92-93.
} 
propriedades rurais, em meio à lida diária dos trabalhadores. Contato com técnica de plantio, trato com gado, costumes e tradições regionais;

- Turismo de Aventura está em moda nos grandes centros do Brasil é essencialmente rural e combina o turismo com a prática de esportes ligados a natureza;

- Turismo místico-religioso é aquele cujo motivo principal do deslocamento seja constituído por razões esotéricas, vinculadas ou não a templos e doutrinas religiosas;

- Ecoturismo é uma modalidade de turismo, relacionada com a conservação do meio ambiente.

Note-se que, especificamente, as modalidades de turismo acima conceituadas têm estreita relação com o tema, já que, em seu conjunto, são tipos de turismo que podem ser desenvolvidos em Brasília e na Região do Entorno.

A compreensão destes conceitos permite entender que é possível se desenvolver modalidades de turismo que assumam um caráter de sustentabilidade. Para o caso especial de Brasília, por exemplo, por se tratar de uma cidade “tombada” como patrimônio histórico mundial, torna-se importante estar atendo e, principalmente, estimular, o surgimento de empreendimentos turísticos que se mostrem responsáveis, não somente em relação ao patrimônio e ao ambiente próprios do local, mas também no que tange à menor influência cultural sobre as comunidades circunvizinhas (Região do Entorno).

Conforme PIRES:

“Turismo desenvolvido em áreas naturais, onde seus consumidores procuram usufruir ao máximo a natureza, minimizando os impactos que possam causar, além de 
desenvolver uma consciência ou compreensão ecológica”. ${ }^{13}$

Segundo WESTERN (1995) a “conservação e turismo que neguem os direitos e interesses das comunidades locais estão fadados ao fracasso, quando não considerados totalmente ilegais”"14.

O turismo está interligado ao meio ambiente, sendo o patrimônio natural uma peça essencial. A política de preservação do meio ambiente visa o controle do crescimento, sem a destruição da originalidade dos atrativos. O turismo sustentável contempla exatamente essa visão de equilíbrio entre o desenvolvimento econômico e a preservação do meio ambiente. Nos dias atuais o maior agressor é o turismo de massa, o qual é desordenado e não tem como base um turismo de qualidade.

RUSCHMANN $^{15}$ declara que durante o seu desenvolvimento, o turismo apresentou fases de relacionamento com o meio ambiente.

“A primeira fase foi de descoberta do meio ambiente. No segundo momento, a proteção era algo desnecessário, alterando o ambiente e causando a sua degradação rápida, principalmente através do turismo de massa, quando ocorreu um domínio brutal do turismo sobre a natureza. A terceira fase foi a de reparação e renovação do turismo através da revalorização do meio ambiente, tendo como norte o conceito de desenvolvimento sustentável e posteriormente o ecoturismo”.

No século XX o turismo se tornou uma das maiores indústrias, seu desempenho é superior à indústria de automóvel, de aço, de eletrônica e à agricultura. Dados do Conselho Mundial de Viagens e Turismo (CMVT) indicam que o setor emprega 127 milhões de trabalhadores (1 em cada 15 no mundo todo). A Organização Mundial de Turismo indica que o turismo internacional cresceu mais de $57 \%$ na década passada ${ }^{16}$.

\footnotetext{
${ }^{13}$ PIRES, P. S. A dimensão conceitual do ecoturismo. São Paulo: 1998, p. 57.

${ }^{14}$ Apud LEMOS, Amália (Org). Turismo: impactos sócio-ambientais. São Paulo: Hucitec, 2001, p. 57.

${ }^{15}$ RUSCHMANN, Doris. Turismo e planejamento sustentável: a proteção do meio ambiente. 8 ed. Campinas (SP): Papirus, 1997, pp. 20-21.

${ }^{16}$ LINDBERG, Kreg., HAWKINS, Donald. Ecoturismo um guia para planejamento e gestão. 2 ed. São Paulo: Senac, 1995.
} 
Várias medidas podem ser adotadas para diminuir os impactos ambientais do turismo como o controle, diminuição ou eliminação dos produtos que causam impactos ao meio ambiente natural, o respeito aos interesses da população local, como suas tradições e cultura, o zelo pela preservação de áreas protegidas ou ameaçadas. O turismo deve respeitar a compatibilidade do uso com a proteção do meio ambiente.

Atualmente, o planejamento da evolução do turismo através do enfoque do Desenvolvimento Sustentável apresenta-se como a forma preventiva ideal para proteção dos meios visitados, conservando a natureza, oferecendo conforto e satisfação ao turista sem agredir a originalidade das comunidades receptivas.

\subsection{Turismo e sustentabilidade}

A repercussão mundial acerca das questões ambientais também teve seu reflexo no turismo, envolvendo o ecoturismo com base no conceito de desenvolvimento sustentável. Esse se caracteriza por uma estreita relação homem-natureza, e apóia-se na necessidade de integrar as áreas econômica e social, com a preservação e a melhor utilização dos recursos naturais, tornando-se assim capaz de preservar o meio ambiente e proporcionar a satisfação das necessidades de sobrevivência das comunidades locais ${ }^{17}$.

Tanto o desenvolvimento econômico quanto à proteção ambiental estão relacionados diretamente, afinal, os bens gerados na sociedade são desenvolvidos, basicamente, a partir de matérias-primas e insumos encontrados na natureza (madeira, minérios, alimentos, água, entre outros). Porém, esta relação não é linear. Isso é um paradigma: problemas ambientais nos países em desenvolvimento, como o Brasil, vêm do desenvolvimento econômico e da falta dele. Sem desenvolvimento econômico, dificilmente esses problemas se resolvem. Assim, mais desenvolvimento econômico não necessariamente significa mais problemas ambientais, e similarmente, menos desenvolvimento econômico não significa menos ou nenhum impacto ambiental. A chave do problema é a maneira como o desenvolvimento é feito. Essa maneira define se

${ }^{17}$ MOLINA, Sérgio. Turismo e ecologia. Bauru (SP): EDUSC, 2001, p. 179. 
o desenvolvimento econômico pode ajudar ou não a melhorar a qualidade ambiental e a qualidade de vida da população ${ }^{18}$.

O conceito de sustentabilidade é conflitante, tornando-se, muitas vezes, mais questão política que ambiental. O conflito nasce das diferenças de interesses, bem como da quase total impossibilidade da ação humana que não provoque efeitos ambientais. Sobre isso se pode ainda dizer, como exemplo, que, em geral, os empreendimentos, se de um lado geram emprego, renda, impostos, benefícios sociais indiretos (aumento da oferta de bens e serviços, entre outros), provocam, por outro lado, variações, quase sempre negativas, no ecossistema (derrubada de matas, lançamento de detritos em rios etc.). O Estado atua como intermediador e, depender do nível de forças sociais que apóiam o uso sustentável dos recursos naturais, podendo interferir favoravelmente na resolução, exercendo poder em função do bem-estar social e ambiental.

O conceito de desenvolvimento sustentável dado pelo relatório da Comissão Mundial sobre Meio Ambiente e Desenvolvimento (CMMAD), gira em torno da satisfação das necessidades humanas básicas e expectativas de vida melhor. Relata, também, que o atual modelo de desenvolvimento não visa essa satisfação. O Relatório lembra que "a pobreza reduz a capacidade das pessoas para usar os recursos de modo sustentável, levando-as a exercer maior pressão sobre o meio ambiente»19.

Promover e desenvolver turismo com bases culturais e ecologicamente sustentáveis, promover e incentivar investimentos em conservação dos recursos naturais e cultuais utilizados, fazer com que a conservação beneficie naturalmente as comunidades envolvidas, ser operado de acordo com os critérios de mínimo impacto para ser ferramenta de proteção e conservação ambiental e cultural, educar e motivar pessoas através da participação e perceber a importância de áreas naturais e culturalmente conservadas, são tarefas a ser desenvolvidas pelo ecoturismo ${ }^{20}$.

\footnotetext{
${ }^{18}$ Idem, p. 180.

${ }^{19}$ CMMAD, Comissão Mundial sobre Meio Ambiente e Desenvolvimento. Nosso furuto comum. 2 ed. Rio de Janeiro: Fundação Getúlio Vargas, 1988, p. 46.

${ }^{20}$ LINDBERG, Kreg \& HAWKINS, Donald E. Ecoturismo - um guia para planejamento e gestão. 4. ed. São Paulo: SENAC, 2002, p. 141.
} 
No caso de Brasília, a antítese existente entre as atividades turística e os ideais de sustentabilidade reside exatamente na dificuldade de se buscar soluções para problemas tais como: o desenvolvimento econômico e turístico da região, simultaneamente à preservação ambiental e patrimonial (lembrando-se que Brasília foi tombada como Patrimônio Cultural da Humanidade). Então, como desenvolver o turismo local, sem afetar a estrutura básica da cidade, com seu "cinturão verde” e, ainda, mantendo-se pouco afetada a cultura das comunidades circunvizinhas.

\subsection{Turismo e ecologia}

No presente trabalho, a relação entre turismo e ecologia é total, visto que não se pretende defender outra idéia senão a de que, o turismo precisa ser desenvolvido 'com base na sustentabilidade econômica. Para tanto, é preciso que os empreendimentos relacionados à tal atividade sejam o menos maléficos possíveis à natureza e às comunidades em que irão se viabilizar. Uma breve análise histórica revela que essa linha de pensamento vem ganhando força a partir da década de 70.

A primeira reunião convocada pela Organização das Nações Unidas (ONU) foi a Conferência das Nações Unidas sobre Meio ambiente Humano, realizada em Estocolmo, na Suécia, em junho de 1972. Naquela época, esse tema ainda não fazia parte da agenda internacional nem era uma preocupação dos governos, que em sua maioria careciam de institucionalidade para o setor. Na declaração final de Estocolmo, ressaltava-se a responsabilidade dos humanos na conservação de seu meio ambiente. Foi o início de debate que ainda não acabou. Como conseqüência da conferência de 1972 foi criado o Programa das Nações Unidas para o Meio Ambiente ${ }^{21}$.

No final do ano de 1983 foi criado a Comissão Mundial sobre Meio Ambiente e Desenvolvimento (CMMAD), através da Assembléia Geral das Nações Unidas, em resposta à preocupação acerca do crescente impacto da atividade humana sobre os recursos naturais. Nesse mesmo ano, foi criada comissão, presidida pelo Primeiro

${ }^{21}$ LAGE, Beatriz Helena Gelas., MILONE, Paulo César. Turismo - teoria e prática. São Paulo: Atlas, 2000 . 
Ministro Gro Harlen Brundtlanda, da Noruega, com a missão de reexaminar os problemas do meio ambiente e o desenvolvimento do planeta, para formular propostas realistas para solucioná-los. Durante três anos, a CMMAD conduziu pesquisas e trabalhou junto ao público, executando estudos específicos feitos por técnicos e consultores líderes em política, negócios, educação, ciência e desenvolvimento ${ }^{22}$.

Em 1987, a comissão lançou relatório conjunto, Our Commom Future (Nosso Futuro Comum), que registrou tanto sucesso quanto falhas no desenvolvimento mundial. A Comissão Mundial sobre Meio Ambiente e Desenvolvimento (CMMAD) encontrou alguns resultados positivos: a expectativa de vida cada vez maior; a mortalidade infantil decaindo; o grau de alfabetização cada vez maior; as promissoras inovações técnico-científicas; e a produção de alimentos crescendo mais que a população mundial $^{23}$.

A maior contribuição do relatório não foi apenas a análise da atual situação mundial, mas também foi dado grande passo para o debate sobre os conceitos de desenvolvimento controlado. O relatório da Comissão Mundial sobre Meio Ambiente e Desenvolvimento (CMMAD) descreve desenvolvimento controlado como sendo não um estado físico de harmonia, mas processo de mudanças no qual a exploração de recursos, o gerenciamento dos investimentos, a orientação do desenvolvimento tecnológico e as mudanças institucionais são compatíveis com o futuro, bem como com as necessidades do presente ${ }^{24}$.

Apoiando-se em diferente e inovadora era de crescimento econômico sustentável e, a fim de combater a pobreza e melhorar as condições da vida humana em todo o mundo, a Comissão Mundial sobre Meio Ambiente e Desenvolvimento (CMMAD) possibilitou o engajamento em vasto aspecto de experiências, perspectivas, aptidões e interesses na procura de soluções criativas e bem sucedidas para problemas em comum.

\footnotetext{
${ }^{22}$ CMMAD, Comissão Mundial sobre Meio Ambiente e Desenvolvimento. Nosso furuto comum. 2 ed. Rio de Janeiro: Fundação Getúlio Vargas, 1988, p. 46.

${ }^{23}$ Idem, ibidem.

${ }^{24}$ CMMAD, Op. Cit., p. 54.
} 
O ecoturismo é um dos negócios mais modernos do setor de lazer dos últimos anos. É também alternativa para o desenvolvimento sustentável em determinados casos. Trata-se de atividade nova. O próprio conceito de ecoturismo data provavelmente da década de setenta. Uma das primeiras estratégias de ação em turismo e sustentabilidade surgiu em 1990, com a Conferência Global 90, na Columbia Britânica no Canadá. Foi a primeira conferência que reuniu integrantes do ramo do turismo, governos, acadêmicos e ONG's para discutir os efeitos degradantes da indústria do turismo sobre o meio ambiente e as possibilidades de um turismo ambientalmente sustentável ${ }^{25}$.

No ano de 1992, realizou-se, em Belize, o Congresso Mundial de Ecoturismo, ocasião em que a atividade foi definida como "turismo dedicado à apreciação da natureza em forma ativa, com o objetivo de conhecer e interpretar os valores naturais e culturais existentes ${ }^{\text {26 }}$.

Ao fim do século XIX, os primeiros parques nacionais pretendiam preservar a natureza do contato humano. Já em meados da década de vinte, a proteção era o conceito chave, e, durante as últimas três décadas do século $\mathrm{XX}$, a gestão das áreas protegidas passou a comandar discurso que identificava a impossibilidade de manter áreas isoladas das atividades humanas. Assim, o grande desafio do século XXI será a questão da gestão integrada, que supõe a participação das comunidades vizinhas, ou inseridas nas áreas de conservação, na gestão sustentável dos espaços naturais ${ }^{27}$.

O ecoturismo é atividade que busca a valorização não só da natureza, mas também dos bens culturais, históricos e arquitetônicos. É através da valorização da cultura e do respeito a tradições, hábitos e tecnologias tradicionais, que os moradores dos lugares visitados são indiretamente beneficiados. Assim, conclui-se que no decorrer do tempo, a idéia evoluiu a partir de enfoque inicial relativo somente à conservação de áreas protegidas, para referências posteriores aos componentes naturais e culturais do ambiente, culminando com a atual preocupação onde são ressaltadas as implicações

\footnotetext{
${ }^{25}$ PINTO, A.C. B. Turismo e meio ambiente: aspectos jurídicos. Campinas: Papirus, 1998, p. 41.

${ }^{26}$ DIAS, G. Freire. Educação ambiental: princípios e práticas. São Paulo: Gaia, 1992, p. 67.

27 TRIGO, Luiz Gonzaga Godoi. Turismo e qualidade - tendências contemporâneas. Campinas (SP): Papirus, 1993, pp. 19-20.
} 
sociais e o estabelecimento da ligação estreita entre o turismo, como atividade comercial e lucrativa, e a participação das comunidades ${ }^{28}$.

A atividade turística ocupa papel importante no mundo moderno, por movimentar grande quantidade de recursos e contribuir para o crescimento da economia. Dentre os segmentos do turismo, o ecoturismo é o que mais cresce, com perspectiva de aumento, decorrente da crescente preocupação com o meio ambiente. É o segmento que mais se aproxima da proposta de desenvolvimento sustentável.

Ao contrário do turismo predatório, turismo de massa, o ecoturismo apresenta-se como estratégia conservacionista do meio ambiente via o turismo, sendo instrumento utilizado para frear o turismo vigente. Segundo ZIFFER ${ }^{29}$, o ecoturismo é a "forma de turismo inspirada primordialmente na história natural de uma área, incluindo suas culturas indígenas”. Assim, tem-se que, na visão do autor citado, para que ocorra o sucesso do ecoturismo, são necessárias algumas etapas ${ }^{30}$ :

- Pesquisa da demanda e oferta;

- Zoneamento turístico-ecológico;

- Seleção de áreas prioritárias;

- Elaboração de projetos de infra-estrutura;

- Execução e controle do projeto. O ecoturismo tem que atentar para a capacidade de carga dos lugares visitados, a integração cultural dos povos, a conservação da base dos recursos naturais utilizados, gerando mecanismos de distribuição de renda. Com este planejamento o ecoturismo traz benefícios como: a) criação de áreas de preservação; b) criação de emprego, lazer e fixação da população no meio rural; c) proporciona a educação ambiental, enfatizando a importância da preservação do meio ambiente.

O rápido crescimento do ecoturismo aumentou a degradação dos recursos

\footnotetext{
${ }^{28}$ LINDBERG, Kreg \& HAWKINS, Donald E. Ecoturismo - um guia para planejamento e gestão. 4. ed. São Paulo: SENAC, 2002, p. 23.

${ }^{29}$ ZIFFER, K. Ecotourism: the uneasy alliance. Washington, 1989, p. 127.

${ }^{30}$ Idem, ibidem.
} 
naturais de interesses turísticos, dificultando o planejamento adequado, gerando conseqüências negativas, como a degradação ambiental decorrente de infra-estrutura inadequada e acúmulo de lixo, gerando poluição, a instabilidade e dependência econômica, quando a geração de emprego e renda é toda decorrente da prática do turismo.

A educação ambiental para atividade turística é ponto importante. É a forma de conhecer, divulgar e preservar o patrimônio histórico, cultural e natural. FIGUEIREDO ${ }^{31}$ ressalta o perigo da falta de conhecimento:

"A atividade turística tem se desenvolvido de tal forma que os indivíduos escolhem o lugar que vão visitar por critérios que não incluem forçosamente a personalidade do lugar, seus aspectos peculiares e especiais, suas características ambientais mais fortes, tais como, a vegetação, o relevo a hidrografia, o povo do lugar e sua cultura, sua música, seus hábitos, sua culinária”.

E sem esse conhecimento fica difícil respeitar. Impera uma grande superficialidade na relação com a natureza e com as populações locais. É impressionante o desconhecimento generalizado que a população tem em relação ao potencial turístico natural do próprio país. Essa ignorância impede a proteção e regulamentação das áreas. De acordo com RUSCHMANN ${ }^{32}$ :

"Independentemente dos diversos enfoques do planejamento turístico, ressalta-se a necessidade de o processo ocorrer de forma integrada, e de que deve ter por objetivo o desenvolvimento coerente dos fenômenos físicos, econômicos, sociais, culturais, técnicos e ambientais, visando à satisfação dos turistas e dos empreendedores, além da preservação do meio ambiente. $\mathrm{Na}$ maioria dos casos a grande motivação das viagens turísticas se refere aos aspectos ambientais. Entretanto, o fluxo descontrolado de turistas poderá descaracterizar completa, e muitas vezes definitivamente, as atrações que motivaram sua visita. Por isso, o planejamento se apresenta como 0 fundamento para 0 desenvolvimento turístico equilibrado evitando assim que o

\footnotetext{
31 FIGUEIREDO, Luiz Afornso Vaz de. Ecoturismo e participação popular no manejo de áreas protegidas: aspectos conceituais, educativos e reflexões. São Paulo: Hucitec, 1997, p. 62.

${ }^{32}$ RUSCHMANN, Doris. Turismo e meio ambiente. Campinas: Papirus, 1990, pp. 65-69.
} 
turista destrua as bases que o fazem existir”.

O desenvolvimento do ecoturismo, no médio e no longo prazos, depende fundamentalmente da preservação do patrimônio ambiental das regiões, promoção e divulgação em âmbito internacional, criação de ofertas atraentes e qualificações dos profissionais da área.

Transferindo-se as idéias aqui apresentadas para o caso de Brasília, nota-se que as razões não são outras senão aquelas já apresentadas ao final do item “2.2”, posto que, o dilema do desenvolvimento com sustentabilidade é justamente alcançar um nível considerável de progresso sem, no entanto, provocar danos elevados ao meio ambiente. Além disso, no caso do turismo em Brasília, deve-se sempre estar atento ao fato de que os aspectos ecológicos são, em grande parte, essenciais como fatores motivadores do turismo local, cujas características (vegetação, cachoeiras, morros, rios, entre outros) ambientais se constituem o maior atrativo.

\subsection{Turismo ecológico no Brasil}

O Brasil tem uma superfície de 8.511.596,3 $\mathrm{km}^{2}$. Essa extensão continental abrange desde regiões equatoriais ao norte até áreas extratropicais ao sul, diferenciadas climática e geomorfologicamente, com uma extraordinária diversidade ecológica.

O ecoturismo no Brasil ainda se desenvolve de forma desordenada, mesmo com a certeza de que o mesmo tenha potencial para tal prática, possui regiões ricas em biodiversidade. No entanto, a imagem que reina no cenário internacional é a da desigualdade social e da violência. Os danos ambientais provocados pelo desenvolvimento descontrolado do turismo podem causar poluição, degradação da paisagem e destruição da fauna e flora, entre outros. A poluição dos recursos hídricos resulta na redução drástica de atividades de recreação e lazer e com isso leva ao afastamento de turistas.

“O ecoturismo praticado no Brasil é uma atividade desordenada, 
impulsionada, quase que exclusivamente pela oportunidade mercadológica, deixando a rigor de gerar os benefícios socioeconômicos e ambientais esperados e comprometendo, não raro, o conceito e a imagem do produto ecoturístico brasileiro nos mercados internos e externos" ${ }^{33}$.

Se o ecoturismo no Brasil encontra-se em estágio de desenvolvimento recente, o momento de introduzir uma política de âmbito nacional para o setor é urgente. Tal política deve orientar governantes para a implantação de estratégias de regulamentação e controle, assim como orientar agências de fomento para criar e facilitar o acesso a incentivos fiscais e financiamentos. Não se pode esquecer do estímulo à capacitação e às tecnologias apropriadas ao empresariado, bem como da promoção da conscientização e educação dos visitantes, entre outras prioridades.

No Brasil, o ecoturismo é discutido desde 1985. No âmbito governamental, a primeira iniciativa de ordenar a atividade ocorreu em 1987, com a criação da Comissão Técnica Nacional, constituída por técnicos do IBAMA e da EMBRATUR, para monitorar o Projeto de Turismo Ecológico, em resposta às práticas existentes à época, pouco organizadas e sustentáveis ${ }^{34}$.

O termo "ecotourism” ou ecoturismo é atribuído ao mexicano Hector Ceballos Lascurains, que deu a primeira definição do conceito em 1983, "viajar para uma região relativamente selvagem com o objetivo específico de estudar, admirar e desfrutar da paisagem, plantas e animais, assim como das manifestações culturais existentes”35.

O turismo ecológico é a base para alcançar modelo sustentável de desenvolvimento. Por ecoturismo entende-se como "viagem responsável a áreas naturais, visando preservar o meio ambiente e promover o bem-estar da população local”36.

Definido por CEBALLUS-LASCURÁIN como:

\footnotetext{
${ }^{33}$ EMBRATUR. Programa ecoturismo: versão preliminar. Brasília: EMBRATUR, 1991, p. 49.

${ }^{34}$ Idem, p. 35.

${ }^{35}$ CEBALLOS- LASCURAIN, Hector. Ecoturismo. México: Diana, 1987, p. 37.

${ }^{36}$ WESTERN, David. Definindo ecoturismo. São Paulo, 1999, p. 127.
} 
"encontro do homem com a natureza em seu estado selvagem", o ecoturismo teve seu conceito ampliado para "modalidade turística, que tem como motivação principal viajar para as áreas naturais, pouco modificadas e livres de contaminação, com o objetivo específico de estudar, admirar e desfrutar ativamente de suas paisagens, plantas e animais silvestres, assim como das manifestações culturais existentes nessas áreas" ${ }^{\text {37. }}$.

Durante a década de 80, e dentro da filosofia ambientalista ou ecologista, o turismo foi amplamente criticado como atividade econômica. Por se tratar de indústria que, embora sem chaminés, criava enormes edificações, como os hotéis à beira mar, trouxe conseqüências irreversíveis, tanto para a população local quanto para o ecossistema. Como crítica a essa situação, surgiram propostas de alternativas ecologicamente mais benéficas para satisfazer às necessidades do turismo de massa: o conceito de Turismo Alternativo. Porém, apesar dos muitos projetos nesse sentido, dos roteiros existentes sobre como elaborar projeto de ecoturismo que vise a sustentabilidade ambiental e, ainda, dos muitos exemplos empíricos, poucos casos puderam ser retirados da realidade e ser usados como modelos de sustentabilidade ${ }^{38}$.

Em junho de 1992, no Rio de Janeiro aconteceu a Conferência das Nações Unidas para o Meio Ambiente e o Desenvolvimento, a Rio 92. Esse evento reuniu em torno de 180 países, preocupados com a questão ambiental. Tinha por finalidade decidir o que deveria ser implementado para promover o Desenvolvimento Sustentável. Sua importância foi a incorporação da possibilidade de desenvolvimento aliado ao meio ambiente saudável. Visava examinar a situação ambiental desde 1972, estabelecer mecanismos de transparência de tecnologias não poluentes aos países subdesenvolvidos e incorporar critérios e regras ambientais no processo de desenvolvimento. Seu objetivo era criar estratégias de acordos internacionais e nacionais para beneficiar a preservação do meio ambiente e a expansão do desenvolvimento ${ }^{39}$.

A Rio 92 enfatizou a importância de política que visasse reduzir os impactos sociais e ambientais causados pelo sistema produtivo, debater sobre modelos de

\footnotetext{
${ }^{37}$ Apud COSTA, Patrícia Côrtes. Ecoturismo. São Paulo: Aleph, 2002, p. 27.

${ }^{38}$ LINDBERG, Kreg \& HAWKINS, Donald E. Ecoturismo - um guia para planejamento e gestão. 4. ed. São Paulo: SENAC, 2002, p. 16.

${ }^{39}$ BOO, E. O planejamento ecotursítico para áreas protegidas. São Paulo: SENAC, 1998.
} 
desenvolvimento onde predominasse a justiça e a conservação do meio ambiente, promover a cooperação internacional que beneficie a preservação ambiental etc. Seu documento de maior relevância, abrangência e alcance foi a “AGENDA 21” que proporcionou nova visão do mundo, um roteiro de ações que relata os compromissos dos países para se tentar alcançar o desenvolvimento sustentável com contenção, equilíbrio e prevenção atribuindo responsabilidade a todos. A viabilidade deste documento depende do empenho de cada Governo. A Agenda 21 foi assinada por aproximadamente 175 chefes de estados e representou consenso internacional de implantação do Desenvolvimento Sustentável. É constituída de recomendações para que todos os países elaborem sua “AGENDA 21” de acordo com suas realidades ${ }^{40}$.

Segundo CRESPO ${ }^{41}$, as principais recomendações da “AGENDA 21” foram:

- Reconhecer a relação entre questão ambiental e desenvolvimento;

- Utilizar a energia de forma mais eficaz e desenvolver fontes de energia solar;

- Promover a educação ambiental dos agricultores e da população em geral;

- Plantar novas florestas e replantar as florestas danificadas;

- Eliminar a pobreza, ajudando os pobres a ganhar a vida, de forma a não contribuírem para os danos ambientais;

- Fixar multas para as pessoas e indústrias que poluem as águas e o meio ambiente;

- Preparar planos nacionais para o tratamento de lixo;

- Exigir que as indústrias adaptem métodos de produção mais seguros e mais limpos;

- Mudar padrões de consumo que destroem uma economia ambientalmente saudável, como o caso dos países ricos e das elites sócio-econômicas locais.

A Agenda 21 Local é processo participativo que visa, através de estratégias, alcançar o desenvolvimento sustentável priorizando seus problemas locais, para com isso subsidiar o sucesso das metas estabelecidas pela Agenda 21 Nacional. De acordo

\footnotetext{
${ }^{40}$ CRESPO, Samyra. Desenvolvimento sustentável: as ONG's devem se engajar na elaboração das Agendas 21. Revista trimestral de debate da fase. Ano 27 nº 77. Ed. Fase, 1998.

${ }^{41}$ Idem, ibidem.
} 
com a EMBRATUR ${ }^{42}$ :

"Ecoturismo é um segmento da atividade turística que utiliza, de forma sustentável, o patrimônio natural e cultura, incentiva a sua conservação e busca a formação de uma consciência ambiental através da interpretação do ambiente, promovendo o bem-estar das populações envolvidas”.

CORIOLANO ${ }^{43}$ define ecoturismo como a viagem que conjuga os princípios da ecologia com os princípios do turismo. Assim, “a essência do turismo é o entretenimento ou o lazer e a essência da ecologia é a conservação ambiental”. SWARBROOKE $^{44}$ afirma que o termo ecoturismo é de difícil definição porque cada sujeito envolvido na prestação do serviço tem visão diferente do que ele venha a ser.

"Para o turista, o ecoturismo é sinônimo de férias modernas, que podem conferir um status elevado a seus praticantes; é freqüentemente identificado com turismo de qualidade. Para a indústria, o ecoturismo é um produto que oferece margens de lucro atraentes e dispõe de um mercado extenso e em expansão. Já para as destinações que tem emergido ultimamente, o ecoturismo é altamente rentável, representando um turismo de volume pequeno que permite diferenciá-lo da concorrência”.

No entanto de acordo com RUSCHEL, os formadores do "trade” ecoturístico assim o definem: “O ecoturismo é toda atividade realizada em área natural com o objetivo de observação e conhecimento da flora, da fauna e dos aspectos cênicos (com ou sem o sentido de aventura); prática de esportes e realização de pesquisas científicas" ${ }^{\prime 4}$.

Por sua vez, GOMES ${ }^{46}$ coloca que:

\footnotetext{
${ }^{42}$ EMBRATUR. Diretrizes para uma política nacional de ecoturismo. Brasília: EMBRATUR, 1994, p. 17.

43 CORIOLANO, Luzia. O ecoturismo e os hóspedes da natureza. <http://www.redebonja.cbj.g12.br> Acesso em: 15.jun. 2003.

44 SWARBROOKE, John. Turismo sustentável, turismo cultural, ecoturismo e ética. São Paulo: Aleph, 2000, p. 39.

${ }^{45}$ Apud SERRANO, Célia., TURINI, Heloísa. Viagens à natureza: turismo, cultura e meio ambiente. 3ed. Campinas: Papirus, 1997, p. 56.

${ }^{46}$ GOMES, Patrício. (Eco)turismo: uma (re)leitura dos discursos. Brasília, 2000. 99f. Dissertação (Mestrado em Gestão e Política Ambiental) - Universidade de Brasília, Brasília, 2000, p. 59.
} 
“...o ecoturismo poderia assumir um outro significado, ser uma atividade que privilegia encontro, em vista dele suscitar outras possibilidades nas relações dos homens e das mulheres entre si e destes com a natureza, desde que os ecoturístas estejam em busca de modificar o seu cotidiano e não fugir dele, e que os nativos se mostrem contra a invasão e sua exclusão do processo, inaugurando a possibilidade de diálogo entre visitantes e anfitriões”.

É notável a diferença de perspectiva com relação ao ecoturismo nas definições da EMBRATUR (1994) e CORIOLANO (2003) e depois, nas apresentadas por SWARBROOKE (2000) e pelo trade do ecoturismo. A última definição dista em maior grau das demais por ter um caráter mais filosófico e transcendente. Cada uma delas, portanto, acarreta implicações diferenciadas. Enquanto a EMBRATUR (1994) emprega termos como 'utilização sustentável’ e 'conservação', CORIOLANO (2003), por sua vez, recorre aos termos ecologia e também conservação, sendo que as duas últimas são mais pragmáticas. Estão mais atentas ao mercado de contemplação que cresce mundialmente e aos ganhos financeiros que isso representa.

Ainda que a EMBRATUR (1994) não consiga dar na prática, conseqüência à definição que assume para si, pelo menos está na órbita onde circula o pensamento (acadêmico ou não) daqueles que pensam em formas de desenvolvimento que não prejudiquem a natureza.

CORIOLANO (2003) aprofunda mais sua visão do tema prescrevendo que o ecoturismo deve conservar e preservar conforme a situação apresentada, distinguindo os locais de pura contemplação e aqueles onde está assegurada a presença humana com intervenções programadas.

SWARBROOKE (2000) é bastante claro. Tem como aspiração para o ecoturismo um futuro compromisso com a sustentabilidade, mas sabe que, para que isso se torne possível, a atividade terá que retornar à mera contemplação e seus empreendedores, por outro lado, devem romper com o trato exclusivamente comercial dos seus serviços. Daí a razão para o autor separar didaticamente turismo sustentável de ecoturismo, almejando que o último venha a ser, no futuro, o que definiu como 
ecoturismo sustentável.

A definição do “trade” é pragmática por outros motivos. Vendo a natureza como grande produto a ser comercializado, somente cabe falar de sustentabilidade quando isso se relacionar imediatamente com lucros, caso contrário, a preocupação com a mesma não tem a importância para ser citada como prioridade a ser gerida pelo setor. Até porque assumir compromissos dessa natureza significa causar impactos de lucros obtidos de subprodutos da viagem e que, sendo deixados de produzir, acabam por ferir inúmeros interesses.

A última definição está em um campo que reivindica o não-consumismo e maiores valores de transcendência durante a viagem, distanciando-se mais dos conceitos do trade e de SWARBROOKE (2000) e menos dos de CORIOLANO (2003) e EMBRATUR (1994), embora os pesos economicista e tecnocrático de ambos sejam fortes.

Em 1994, iniciativa conjunta entre o Ministério de Indústria, Comércio e Turismo e o Ministério do Meio Ambiente, dos Recursos Hídricos e da Amazônia Legal, propôs as Diretrizes para a Política Nacional de Ecoturismo. Tais diretrizes têm, desde então, norteado oficialmente o desenvolvimento do ecoturismo no Brasil. Segundo essas diretrizes, o conceito nacional de ecoturismo pode ser expresso como:

“um segmento da atividade turística que utiliza forma sustentável o patrimônio natural e cultural, incentiva sua conservação e busca a formação de uma consciência ambiental através da interpretação do ambiente, promovendo o bem- estar das populações envolvidas".

O documento traz as principais recomendações e diretrizes para governos, empresas privadas, entidades não-governamentais, acadêmicas de pesquisa, agências de fomento e investimentos, municípios e comunidades envolvidas com o ecoturismo, atividade que vem apresentando forte crescimento desde a Conferência RIO 92. 
Assim, segundo LINDBERG \& $\mathrm{HAWKINS}^{47}$, o ecoturismo representa alternativa de desenvolvimento econômico sustentável que utiliza racionalmente os recursos naturais de cada região, sem comprometer a capacidade de renovação e conservação. Nesse segmento, diversos nichos de mercado são identificados como formas de praticar o ecoturismo: contemplação da flora, fauna e cultura local; safáris fotográficos; trilhas; mergulhos de observação; atividades esportivas em rios, montanhas e cachoeiras.

A possibilidade do ecoturismo como alternativa de desenvolvimento sustentável, tem conduzido ao rápido crescimento do mercado de produtos turísticos denominados 'verdes'. Surgem regras de regulamentação que cresceram ao lado dessas atividades, usadas para indicar modelo seguro de práticas definidas como sustentáveis, utilizadas, tanto internamente por entidades privadas, quanto por organismos públicos ligados ao turismo e por membros da sociedade civil, quais sejam ${ }^{48}$ :

- Compatibilizar as atividades ecoturísticas com a conservação das áreas naturais: promover a regulamentação do ecoturismo, de modo a adotar o segmento de estrutura legal própria, harmonizada com as esferas federal, estadual e municipal, de critérios e parâmetros adequados ao desenvolvimento da atividade; prevê a elaboração e a revisão das normas legais, a definição de responsabilidades e a priorização das áreas em que a atividade do ecoturismo seja melhor orientada e conduzida.

- Fortalecer a cooperação e interação interinstitucional, promovendo a articulação e o intercâmbio de informações e de experiências entre os órgãos governamentais e entidades do setor privado.

- Possibilitar a participação efetiva de todos os segmentos atuantes no setor: consiste em conscientizar o turista para que tenha postura correta, adequada

\footnotetext{
${ }^{47}$ LINDBERG, Kreg \& HAWKINS, Donald E. Ecoturismo - um guia para planejamento e gestão. 4. ed. São Paulo: SENAC, 2002, p. 225.

${ }^{48}$ LINDBERG, Kreg \& HAWKINS, Donald E. Ecoturismo - um guia para planejamento e gestão. 4. ed. São Paulo: SENAC, 2002, p. 226.
} 
à preservação ambiental. Para que a comunidade local veja no ecoturismo alternativa econômica viável e tenha consciência do seu papel e da importância dos valores culturais, naturais e históricos, para a perfeita visita do turista àquela localidade e o empreendedor tenha responsabilidade da importância da sustentabilidade do meio.

- Promover a capacitação de recursos humanos. É a principal ação a ser desenvolvida, pela carência de mão-de-obra de qualidade, que pode ser adquirida por meios de Oficinas de Capacitação de Ecoturismo e outros cursos que tenham relação com a atividade turística.

- Promover, incentivar e estimular a criação e melhoria da infra-estrutura para a atividade de ecoturismo: criar e adequar incentivos para o aprimoramento de tecnologias e de serviços, a ampliação de infra-estrutura existente e a implementação de novos empreendimentos turísticos. Essa ação prevê que os recursos destinados ao segmento sejam utilizados de forma ordenada e adequada, buscando-se parcerias para a implementação das atividades.

- Promover o aproveitamento do ecoturismo como veículo de educação ambiental. Essa ação busca orientar o turista quanto à conduta adequada nas áreas visitadas e que tenha com postura ecologicamente correta.

O ecoturismo bem sucedido não pode prescindir de planejamento sistematizado, com visão de longo prazo e estrita obediência a legislação e exige gestão adequada, o que significa poder contar com administradores competentes, providos de conhecimentos técnicos.

Pode-se dizer que o sucesso da atividade será sempre a resultante de inúmeros fatores, destacando-se a necessidade de cada organização, instituição, seja pública ou privada, voltar-se para o futuro, pronta a assimilar novas informações.

O planejamento é o processo contínuo que busca alternativas que possam ajudar 
na tomada acertada de determinadas decisões. Permite a escolha, dentre as diferentes alternativas, daquela que oferece as melhores chances de sucesso, levando em consideração os recursos, a equipe, o tempo e a estrutura disponíveis.

O planejamento permite criar o cenário que se deseja, evitar situações indesejáveis e adaptar-se ao inesperado, isto é, para transformar atrativos em produtos ecoturísticos é preciso planejamento. Assim é possível identificar:

- O que a localidade tem a oferecer;

- Quais são os seus pontos fortes e fracos;

- Quais são as responsabilidades e os papéis dos diversos agentes ligados ao ecoturismo;

- Quais são os grupos de pessoas que consomem ou estão dispostas a consumir produtos ecoturísticos;

- Produtos que possam competir no mercado ecoturístico, oferecendo atrativos que estimulam o mercado consumidor adequado.

Os impactos do ecoturismo referem-se ao conjunto de modificações ou seqüências de eventos causados pelo desenvolvimento da atividade em localidades receptoras. Tais impactos resultam de processo e não constituem eventos pontuais ${ }^{49}$. Seus motivos têm natureza e intensidade diversas, mas os resultados são geralmente irreversíveis quando ocorre no meio ambiente natural.

A proteção das espécies da fauna e da flora nativas de um país ou região só pode ser feita efetivamente pela preservação de partes significativas de seus ambientes naturais ou habitats. Assim, foram criadas as Unidades de Conservação (UC), abrangendo amostras destes ambientes naturais, tendo como finalidade sua preservação e/ ou conservação e se constituindo instrumento de proteção da biodiversidade do País.

Preservar o ecossistema é garantir, para a região, vida em equilíbrio. A destruição de algumas espécies pode provocar o aumento populacional de outras,

${ }^{49}$ RUSCHMANN, Op. Cit., p. 33. 
gerando, assim, desequilíbrios com conseqüências danosas a todos que habitam o local. É também através da proteção do ambiente que se pode assegurar maior volume e a melhoria da qualidade das águas, condições que hoje se encontram ausentes em grande parte dos mananciais. Em ambientes preservados quem ganha é a natureza, portanto, todos ganham.

No ecoturismo, o desenvolvimento sustentável preocupa-se com o impacto causado à natureza, valoriza os aspectos histórico-culturais do local e utiliza recursos naturais e mão-de-obra da região para a realização de projetos integrados ao meio ambiente.

A fragilidade dos ecossistemas naturais, muitas vezes, não comporta o número elevado de visitantes e, menos ainda suporta o tráfego excessivo de veículos pesados. A infra-estrutura necessária, se não atender a normas pré-estabelecidas, pode comprometer de maneira acentuada o meio ambiente, com alterações na paisagem, na topografia, no sistema hídrico e na conservação dos recursos naturais relacionados à flora e à fauna.

O ecoturismo, mais do que qualquer outra forma de turismo na natureza, depende da qualidade do ambiente visitado. Esse é mais um motivo pelo qual a atividade deve ser controlada e seus potenciais impactos negativos minimizados pelo manejo ${ }^{50}$.

Segundo o Ministério do Meio ambiente (MMA), o ecoturismo apresenta significativo impacto positivo e negativo nos aspectos econômico, social e ambiental, como mostrado a seguir.

Dessa forma, tem-se que, em se tratando do ponto de vista ecológico, os principais pontos positivos relacionados são ${ }^{51}$ :

- Destinação dos recursos financeiros para a conservação do meio ambiente e estímulo à recuperação das áreas protegidas;

\footnotetext{
${ }^{50}$ Idem. p. 34.

${ }^{51}$ http://www.mma.gov.br (acesso em 04.09.2003, às 22:15).
} 
- Estimula levantamentos de fauna e flora e incentiva a pesquisa científica;

- Turismo feito em pequena escala;

- É mais ativo do que outras formas de turismo;

- Promove a educação ambiental e maior consciência ambiental nas populações;

- Viabiliza tecnologias ambientalmente sustentáveis;

- Empreendido por turistas esclarecidos e bem educados, conscientes das questões relacionadas a sustentabilidade, além de ávidos por aprender mais sobre estes temas;

- Estimula a implantação de infra-estrutura básica, saúde, comunicação, segurança, educação e comércio;

- Valoriza áreas naturais e cria condições de unir desenvolvimento e conservação;

- Menos espoliativo das culturas e da natureza locais do que as formas “tradicionais” de turismo.

Ainda em relação ao enfoque ecológico os pontos negativos encontrados são ${ }^{52}$ :

- Mudanças numéricas nas populações silvestres;

- Alterações no comportamento, hábitos alimentares e na reprodução dos animais silvestres pelo excesso de visitação e/ou presença de lixo;

- Comércio ilegal de espécies silvestres e de artesanatos que utilizam órgãos, penas ou couro de animais;

- Poluição do ar, água, solo, sonora e visual;

- Abertura de estradas, trilhas e atalhos inadequados;

- Compactação e erosão do solo;

- Todos conhecemos os problemas causados pelo turismo de massa. E um destino de ecoturismo pode se tornar turismo de massa, quando muito divulgado e concebido de forma irresponsável;

- O ecoturismo deve dizer respeito a ecossistemas e ecossistemas dizem respeito à vida selvagem e às pessoas. Para os ecoturistas, portanto, as

\footnotetext{
52 http://www.mma.gov.br (acesso em 04.09.2003, às 22:21).
} 
pessoas e a vida selvagem devem ter a mesma importância.

Quanto ao ângulo econômico, os principais pontos positivos são ${ }^{53}$ :

- Aumento da renda e do número de emprego na região;

- Utilização da infra-estrutura já existente;

- Desenvolve-se com produtos locais;

- Complementa outras atividades econômicas.

Considerando-se ainda o ângulo econômico, os principais pontos negativos são ${ }^{54}$ :

- Ocorrência do aumento da inflação;

- Na baixa temporada causa o desemprego, pois as atividades turísticas dependem das estações do ano;

- Pode haver prejuízos econômicos como conseqüências, de boatos problemas como doenças, mudanças no setor financeiro;

- A economia pode ficar dependente do ecoturismo como principal fonte de renda.

Pelo prisma social, tem-se que os principais pontos positivos são ${ }^{55}$ :

- Contribui para a educação;

- Estimula o entendimento e a paz;

- Reduz barreiras entre as pessoas, em razão da raça, cor, sexo, origem cultural, política ou religiosa;

- Reforça a conservação de herança e tradições, valoriza a cultura local.

Também pelo prisma social tem-se que os principais pontos negativos são ${ }^{56}$ :

\footnotetext{
53 http://www.mma.gov.br (acesso em 04.09.2003, às 22:40).

54 http://www.mma.gov.br (acesso em 04.09.2003, às 22:44).

55 http://www.mma.gov.br (acesso em 04.09.2003, às 22:55).

56 http://www.mma.gov.br (acesso em 04.09.2003, às 22:59).
} 
- Gera antipatia pelo excesso de visitantes;

- Descaracterização da cultura local;

- Desentendimento entre a comunidade local e novos mercados;

- Estimula aumento da criminalidade.

Dessa forma, tendo sido expostas aqui algumas das principais premissas e alguns dos conceitos mais significativos sobre turismo e ecoturismo, passa-se a apresentar, no próximo capítulo, o perfil do empreendimento ecoturístico. 


\section{PERFIL DO EMPREENDIMENTO DE ECOTURISMO}

Nesse trabalho, como já explicado, o empreendimento ecoturístico que se buscou focar é aquele realmente comprometido com os ideais de sustentabilidade, ou seja, aquele que, além do lucro, vise também a preservação ambiental, ou ao menos o menor efeito devastador possível ao ecossistema. Assim, conceituar o empreendimento ecoturístico se faz necessário, como forma de ressaltar os valores aos quais deve estar relacionado.

A consciência ecológica é fator preponderante para a sustentabilidade do meio ambiente. Com relação à prática de ecoturismo, esta requer o máximo de responsabilidade na conservação dos recursos naturais e culturais de determinada região explorada. A empresa deve seguir os mesmos princípios adotados na administração verde ou na gestão ambiental dos negócios de ecoturismo que segundo a OCE ${ }^{57}$ envolvem:

- Eficiência, conservação e administração de energia;

- Reduzir, reutilizar e reciclar qualquer material possível para evitar o desperdício;

- Empregar tecnologias e materiais locais de fontes sustentáveis;

- Envolver funcionários, comunidades, fornecedores e clientes em assuntos ambientais na conscientização;

- Promover a integração e a interação entre os turistas e as comunidades locais receptoras;

- Conservação e uso sustentável dos recursos naturais;

- Informação e interpretação ambiental;

- É um negócio que deve gerar recursos;

- Reverter em benefício para a comunidade local e para a conservação dos recursos naturais e culturais;

- Deve ter envolvimento da comunidade local.

\footnotetext{
${ }^{57}$ OCE, Oficinas de Capacitação em Ecoturismo. Disponível em: < http//www.ecosfera.com.br>. Acesso em: 15 jul. 2003.
} 
Critérios do ecoturismo:

- Manejo e administração verde do empreendimento;

- Parceria entre os setores governamentais e não governamentais locais, regionais e nacionais;

- Educação ambiental para o turista e para a comunidade local;

- Guias conscientes, interessados e responsáveis;

- Planejamento integrado, com preferência à regionalização;

- Promoção de experiências únicas em locais exóticos;

- Monitoramento e avaliação constante do empreendimento;

- Turismo de baixo impacto;

- Código de ética para o mercado de ecoturismo.

Princípios do ecoturismo:

- Conservação e uso sustentável dos recursos naturais e culturais;

- Informação e interpretação ambiental;

- É um negócio e deve gerar recursos;

- Deve haver reversão dos benefícios para a comunidade local e para a conservação dos recursos naturais e culturais;

- Deve ter envolvimento da comunidade local.

De modo geral, o ecoturista é consumidor exigente e está sempre alerta às mudanças ambientais e, assim, torna-se preocupado em contribuir com a manutenção dos recursos naturais e do equilíbrio dos ecossistemas. Esse consumidor tem adquirido consciência de que não está isento de culpa e começa a se questionar sobre como são obtidos os produtos que consome.

Esse fenômeno parece ser a nova tendência de mercado à medida que cada vez mais a humanidade se depara com alertas sobre degradações ambientais, e não esquecendo que a natureza, por estar em constante mutação, responde às intervenções antrópicas (humanas), necessitando de conservação. 
Os consumidores do ecoturismo possuem características próprias e, de certa forma, conhecidas do mercado. São aqueles que possuem bom nível cultural, geralmente com formação universitária, possuem médio e alto poder aquisitivo e idade compreendida entre 20 e 40 anos.

Outras características dizem respeito às motivações para a viagem de ecoturismo, sempre buscando o contato direto com a natureza, priorizando os locais exóticos e a integração e respeito à cultura da comunidade local. Outros aspectos são citados de acordo com a OCE ${ }^{58}$.

- Oriundos de grandes centros urbanos;

- Possuem o cotidiano agitado, estressante, isento de contato com a natureza;

- Ávidos por contato positivo com o meio ambiente e atividades de relaxamento, contemplação e lazer;

- Procuram acesso a informações sobre o meio ambiente e sobre problemas ambientais;

- Procuram ambientes e culturas diferentes, incomuns e até exóticos;

- Possuem consciência de que pagam mais caro por programas cultural e ambientalmente corretos;

- Preocupados com a qualidade do ambiente e com a qualidade de vida da comunidade local e

- Alguns se predispõem a contribuir, interagindo ou consumindo na comunidade.

\subsection{Direito ambiental}

Na década de 70 a escala e a velocidade dos projetos de desenvolvimento do governo militar atingiram um clímax que não resultou apenas em recessão econômica, mas também em uma gama de desastres ambientais, desacreditando sua propalada

\footnotetext{
${ }^{58}$ OCE, Oficinas de Capacitação em Ecoturismo. Disponível em: < http//www.ecosfera.com.br>. Acesso em: 15 jul. 2003.
} 
preocupação com a segurança nacional. Críticas foram feitas à viabilidade de projetos de desenvolvimento em florestas tropicais, mas os emissários brasileiros em encontros internacionais sobre a questão tendiam a desprezá-las, preferindo enfatizar, em seu lugar, as metas extremamente otimistas de tais programas.

Tais programas, executados em sua maioria na região da Mata Atlântica remanescente, implicavam em riscos à sua sobrevivência. O programa do álcool rapidamente se tornou uma causa maior de desmatamento. Aceleraram-se a dragagem e o aterro na região de Campos, para expandir os canaviais, quase extinguindo seus lagos.

As políticas ambientais no Brasil vêm coexistindo em diferentes períodos, com concepções distintas, especialmente marcadas nas décadas de 70 e 80 por um modelo centralizador e uma institucionalização fragmentada. As mudanças e o contexto dos anos 70 com relação aos problemas ambientais demonstram que o movimento ambientalista brasileiro "estrutura-se no seu período formativo como movimento bissetorial constituído por associações ambientalistas (ONGs) e o Poder Público”. 59

À época, sob a égide da ditadura militar, o Governo Federal ditava as políticas ambientais sem consultar estados ou municípios, determinando o que se deveria fazer, sem conhecer as realidades locais, muitos menos sem pesquisar ou estudar os impactos ambientais que ocorreriam nos ecossistemas, fazendo megas-projetos, os quais causavam danos ao meio ambiente. ${ }^{60}$ Paralelamente à esfera pública, o movimento ecológico estava se tornando, se não um movimento de massa, pelo menos mais político. A ecologia passava cada vez mais a se alojar nos partidos da esquerda.

O ambientalismo podia atender a objetivos ideológicos de apelo tradicional mais amplo. Afirmava-se que a destruição florestal era conseqüência do ônus da dívida externa do país: a necessidade urgente de pagar taxas de juros em caras divisas obrigava

\footnotetext{
${ }^{59}$ MACHADO, P. A. L. Direito Ambiental Brasileiro. São Paulo: RT, 1999, p. 12.

${ }^{60}$ BARROSO, L. R. O Direito Constitucional e a Efetividade de suas Normas: limites e possibilidades da Constituição Brasileira. Rio de Janeiro: Renovar, 1996, p. 279. Como é o caso da barragem de Tucuruí, onde foi interceptado um dos rios mais importantes da região amazônica, sem se importar com a reprodução dos peixes, haja vista que os mesmos sobem o rio para se reproduzir por ocasião da piracema, tão pouco com os ribeirinhos que sofreram tanto com a mudança do meio em que viviam pois os peixes simplesmente desapareceram.
} 
o Brasil a saquear seu patrimônio natural em favor das exportações. Procuravam não ser influenciados pelo governo, mas influenciá-lo. A estratégia era pressionar o governo a assumir suas responsabilidades.

A política centralizadora começa a enfraquecer na medida em que a sociedade se mobilizou e exigiu o fim do governo militar, fazendo com que, já na década de 80, a sociedade como um todo, preocupados com a questão ambiental, começassem a se mobilizar em associações ambientalistas, com o objetivo de defender uma política ambiental racional para o desenvolvimento do país com ordenação. ${ }^{61}$

À mesma época, já se falava em "desenvolvimento sustentado", 62 como forma de buscar equilíbrio entre a preservação dos recursos naturais e o progresso econômico.

O movimento ecológico internacional havia surgido no século XIX com manifestações isoladas, sem caráter globalizado, que surgiu há mais de 35 anos. Porém, em 1968, nos Estados Unidos, foi que o ambientalismo ganhou forma reconhecível, fazendo com que em vários paises surgissem comitês ambientais. Em 1972 em Estocolmo a ONU realizou a I Conferencia Internacional para debater o meio ambiente, onde a maioria dos paises defendeu o direito a poluir em nome do desenvolvimento, estando o Brasil entre eles. Iniciada a luta na defesa do meio ambiente, o Governo Federal começou a descentralizar as políticas ambientais aos estados e com o advento da CF/88, foi possível alcançar os municípios que começam ainda que incipiente, gerir parcelas de suas riquezas ambientais com órgãos gestores próprios, em alguns municípios criados a partir de suas Leis Orgânicas em 1990, pois determinadas Unidades de Conservação ainda estão ou com os estados ou com a União. ${ }^{63}$

Atualmente, o Brasil possui um vasto conjunto de leis cujo objetivo precípuo é

\footnotetext{
${ }^{61}$ MACHADO, P. A. L., Op. Cit., p. 13.

${ }^{62} \mathrm{O}$ termo refere-se à melhoria das condições de existência dos povos, utilizando recursos naturais para a produção de bens, de tal modo que estes continuem disponíveis para as futuras gerações. Essa definição reconhece claramente a necessidade de melhoria da qualidade de vida da população atual, que depende da utilização mais sensata e eficiente de recursos energéticos. Assim, é necessário que mesmo as formas mais fundamentais de consumo (alimentos, remédios, vestimentas, moradia e transporte) sejam efetuadas de modo eficiente. MACEDO, R. K. Gestão Ambiental de Territórios - Os Instrumentos Básicos para a Gestão Ambiental de Territórios e Unidades Produtivas. Rio de Janeiro: ABES, AIDIS, 1994, p. 37.

${ }^{63}$ Idem, ibidem.
} 
a defesa do meio ambiente. São muitas as leis federais que tratam da questão em tela, dando, cada uma delas, ênfase maior a um determinado tipo de recurso natural. Por essa razão é que há na legislação textos que regulam aspectos eminentemente pontuais da defesa do meio ambiente (Código Florestal, Lei de Proteção à Fauna, Código de Águas), textos mais sofisticados, mas ainda relacionados com setores específicos do meio ambiente, e outros, ainda, mais recentes, que visam a proteção global do meio ambiente (como a CF de 1988, a Lei da Política Nacional de Meio Ambiente - Lei Federal n. ${ }^{\circ}$ 6938/81 - e certos documentos internacionais, como as Declarações de Estocolmo e do Rio de Janeiro de 1992 sobre Meio Ambiente e Desenvolvimento). Entretanto, em decorrência de fatores culturais e sociais de diversas ordens, esse farto aparato jurídico não tem sido suficiente para conter o avanço dos problemas ambientais no Brasil. Contudo, conforme afirma MIRRA: ${ }^{64}$

"Em que pese a característica fragmentária da legislação ambiental entre nós, é ainda assim possível extrair desse conjunto de normas um sistema coerente e lógico. Aliás, exatamente em função dessa peculiaridade do Direito Ambiental Brasileiro é que se torna verdadeiramente imperativa tal operação, como única maneira de se chegar a uma efetiva proteção do meio ambiente.”

No entanto, para que se efetive a premissa de MIRRA, necessário se faz que o Judiciário atue com maior ênfase nos temas relacionados ao meio ambiente, não apenas se limitando às questões processuais, mas determinando as prioridades das políticas públicas ambientais, assumindo, assim, seu novo papel na democracia contemporânea.

A problemática da efetividade do Direito Ambiental está intrinsecamente ligada à questão do acesso à justiça, exprimindo um referencial básico do Estado democrático: a garantia da dignidade da pessoa humana. PERELMAN, ${ }^{65}$ a respeito da salvaguarda dos direitos humanos, põe em relevo os seguintes argumentos:

"A noção de direitos humanos implica que se trata de direitos atribuíveis a cada ser humano enquanto tal, a pessoa possui uma dignidade que lhe é própria e merece respeito enquanto sujeito moral livre, autônomo e responsável. Daí a situação ímpar que lhe

\footnotetext{
${ }^{64}$ MIRRA, A. L. V. “Fundamento do Direito Ambiental no Brasil”, in: RT, n. ${ }^{706}$, agosto de 1994, p. 8.

${ }^{65}$ PERELMAN, C. Ética e Direito. São Paulo: Martins Fontes, 1996, pp. 400-401.
} 
é reconhecida e que o direito tem de proteger. Se é o responsável pela dignidade da pessoa que fundamenta a doutrina jurídica dos direitos humanos; esta pode ser considerada doutrina das obrigações humanas, pois cada um tem a obrigação de respeitar o indivíduo humano, em sua própria pessoa bem como na das outras. Assim também o Estado, incumbido de proteger esses direitos e de fazer que se respeitem as obrigações correlativas, não só é por sua vez obrigado a abster-se de ofender esses direitos, mas tem também a obrigação de criar as condições favoráveis ao respeito à pessoa por parte de todos os que dependem de sua soberania.”

Nesse sentido, tem-se que, concretizar o respeito à dignidade da pessoa humana exige que estejam asseguradas condições básicas de vida, nessa medida, devem estar garantidas: a vida em si, o direito à habitação, à saúde, ao meio ambiente hígido, ao emprego, à participação política, à liberdade, à segurança, entre outras, pois isso constitui a expressão das prerrogativas do cidadão em um Estado. Uma parcela significativa da população do planeta encontra-se alijada das condições mínimas de vida. Nesse sentido, cabe afirmar que poucas pessoas têm o privilégio de desfrutar de uma vida com qualidade. Então, como alcançar a adesão social às normas quando parte da população não tem um teto sob o qual morar, habitando em áreas sob condições insalubres, demonstrando carência de informações técnicas de manejo sustentável? Ou como falar em preservar a biodiversidade, se a própria vida humana não é valorizada? Não se deve justificar a falta de efetividade das normas por desinteresse da população. Há, sim, um processo de alienação como resultado da carência de acesso à educação, à informação, aos direitos básicos que redundam na falta de acesso à justiça.

A população tem grande desconfiança dos operadores do direito e do aparelho judicial. A via judicial é, muitas vezes, vista como uma máquina burocrática, morosa e opressora. Uma instituição que intimida. É necessário, por conseguinte, desmistificar o Direito, romper a barreira psicológica que afasta o cidadão da esfera jurídica. Como ensina CAPPELLETTI: ${ }^{66}$

“A assistência jurídica significa mais do que a simples representação perante os tribunais. Ela implica auxílio para tornar

\footnotetext{
${ }^{66}$ CAPPELLETTI, M. Acesso à Justiça. Porto Alegre: Sérgio Antônio Fabris Editor, 1988, p. 143.
} 
as pessoas mais ativamente participantes das decisões básicas, tanto governamentais quanto particulares, que afetem suas vidas.”

Quanto a isso, a necessidade de informação é essencial. Acompanhando a segura orientação de CASTRO: ${ }^{67}$

"Impõe-se ressaltar que o concurso da sociedade civil é condição primária para a plena eficácia social da legislação ambiental. Sem a aderência da cidadania ativa e das instituições emanadas do corpo social em torno do ideário preservacionista, frustra-se por inteiro o esforço governamental e legislativo que já se logrou implantar. Enfim, sem a força do povo, a própria Constituição democrática, que hoje bem preside o sistema normativo brasileiro, fica relegada ao plano estéril das intenções retóricas e sem aptidão para exercer o papel transformador e civilizatório da comunidade nacional.”

A respeito da necessidade de conscientização do cidadão sobre a participação no processo de preservação do meio ambiente, FIGUEIREDO ${ }^{68}$ enfatiza que:

“A atuação judicial descontrolada, não aliada a um efetivo trabalho de preparação política da comunidade afetada (conscientização da importância de tal ação) pode vir em detrimento da própria educação ambiental da população, incumbência do Poder Público, nos termos do art. 225, parágrafo $1^{\circ}$, VI, da CF. Com efeito, é necessário que todos compreendam a importância da aplicação do princípio do desenvolvimento sustentável. Na hipótese de interdição de uma atividade lesiva ao meio ambiente, necessário se faz esclarecer à comunidade afeta a tal atividade da imprescindibilidade da cessação do ato danoso ao patrimônio ambiental.”

As informações ambientais de que dispõem os órgãos públicos têm que ser passadas ao público, lembrando da imprescindibilidade da decodificação, para que, assim, haja um real acesso a informação. O caminho para a conservação ambiental é a educação. Dessa forma tornar-se-ia possível uma reflexão sobre os padrões culturais vigentes, onde a meta é a mudança de atitudes coletivas que venham a traduzir a adoção

\footnotetext{
${ }^{67}$ Apud GUEERA, I. F. A Efetividade do Direito Ambiental, in: Revista do Instituto Brasileiro de Advocacia Pública, n. ${ }^{\circ}$ 2. São Paulo: Max Limonad, 1998, pp. 143-153.

${ }^{68}$ FIGUEIREDO, G. J. P. de. Reengenharia do Estado: a Procuradoria-Geral do Estado e a Polícia Florestal na Proteção do Meio Ambiente. Boletim do Instituto Brasileiro de Advocacia Pública, ano III, n. ${ }^{\circ}$, junho 1997, pp. 16-17.
} 
de um padrão de consumo mais razoável, que leve a observância de medidas tais como: reciclagem, reutilização de materiais e utilização de tecnologias não poluentes. $O$ conceito de educação ambiental definido por REIGOTA ${ }^{69}$ vem ao encontro dessa linha de argumentos:

\begin{abstract}
"A educação ambiental deve ser entendida como educação política, no sentido de que ela reivindica e prepara os cidadãos para exigir justiça social, cidadania nacional e planetária, autogestão e ética nas relações sociais e com a natureza. A ética ocupa um papel de importância fundamental na educação ambiental. O homem contemporâneo vive profundas dicotomias. Dificilmente se considera um elemento da natureza, mas como um ser à parte, observador e/ou explorador da mesma. Esse distanciamento fundamenta suas ações tidas como racionais, mas cujas conseqüências graves exige dos homens, nesse final de século, respostas filosóficas e práticas para acabar com o antropocentrismo e o etnocentrismo. A educação ambiental crítica está, dessa forma, impregnada na utopia de mudar radicalmente as relações que conhecemos hoje, sejam elas entre a humanidade, sejam entre esta e a natureza.”
\end{abstract}

$\mathrm{BOBBIO}^{70}$ explica que o controle público sobre o poder só se torna possível quando a visibilidade e o direito à informação são assegurados. Claro, não bastam as informações em si, já que o cidadão precisa saber e conhecer aquilo que está sendo decidido. No campo das organizações governamentais é importante evitar que estas atuem de forma “enclausurada”. É imprescindível a formação de equipes interdisciplinares ${ }^{71}$ com capacitação para oferecer propostas novas, estabelecer uma comunicação interinstitucional, de forma a consolidar um canal de comunicação entre os vários segmentos da área jurídica. Nessa mesma linha de pensamento, FIGUEIREDO ${ }^{72}$ acentua que:

“Urge que os Estados, valendo-se dos órgãos que já dispõe (Instituições de Advocacia Pública, Ministérios ou Secretarias do

\footnotetext{
${ }^{69}$ REIGOTA, M. O Que é Educação Ambiental. Primeiros Passos. São Paulo: Brasiliense, 1994, pp. 1011.

${ }^{70}$ BOBBIO, N. O Futuro da Democracia: uma defesa das regras do jogo. $3^{\mathrm{a}}$ ed. Rio de Janeiro: Paz e Terra, 1987, p. 30.

${ }^{71}$ Tendo em vista que a análise da temática ambiental exige uma gama dos mais variados profissionais (biólogos, geólogos, economistas, juristas, engenheiros, entre outros).

${ }^{72}$ FIGUEIREDO, G. J. P., Op. Cit., pp. 16-17.
} 
Meio Ambiente e Secretarias de Segurança Pública, estas focalizadas na Polícia Florestal), procedam ao que poderíamos chamar de sua reengenharia, ou de reestruturação de suas atividades compartimentadas.”

Para a construção da cidadania participativa deve-se procurar agir com coerência, através do pequeno lume da razão que atravessa nosso caminho. WALCACER $^{73}$ enfatiza que a legislação ambiental precisa ser melhor explorada e que, somente através de uma profunda reformulação no processo de divisão de riqueza haverá alguma esperança de melhora na qualidade de vida.

A Lei n. ${ }^{\circ}$ 6.938/81 (Política Nacional do Meio Ambiente) estabeleceu uma hipótese de ação civil pública ambiental, de cunho material. Mas, foi com a Lei n. ${ }^{\circ}$ 7.347/85, que a ação civil pública de caráter processual, teve o seu perfil definido. ${ }^{74} \mathrm{O}$ meio ambiente é, talvez, o interesse que tem maior difusão, pois “pertence a todos e a ninguém em particular; sua proteção a todos aproveita e a sua postergação a todos em conjunto prejudica". ${ }^{75}$

O descumprimento da legislação ambiental, por má-fé ou ignorância, ante a quantidade de leis esparsas, tem causado efetivo prejuízo à natureza, sendo a Ação Civil Pública o principal instrumento pelo qual pode-se fazer respeitar a legislação vigente, constituindo-se meio para a população em geral buscar reparar ou minimizar tais danos. Do "Documento Oficial do Congresso: o Ministério Público e a Defesa do Meio Ambiente”, evento paralelo ao Rio 92, realizado nos dias 03, 04 e 05 de maio de 1992, na cidade de Angra dos Reis, Estado do Rio de Janeiro, destaca-se:

“A existência secular no direito pátrio, de normas de proteção ambiental não constituiu em óbice à escalada de degradação do nosso patrimônio natural. $\mathrm{O}$ desrespeito à legislação é compreensível em razão de dois fatores básicos: a ausência de uma consciência social sobre o problema ecológico e a falta de imperatividade do comando legal, decorrente sobretudo da

\footnotetext{
${ }^{73}$ WALCACER, F. C. Meio Ambiente Urbano no Brasil. São Paulo: RT, 1993, p. 146.

${ }^{74}$ FREITAS, V. P. (Org.). Direito Ambiental em Evolução. Curitiba: Juruá, 1998, p. 275.

75 TOURINHO NETO, F. C. Dano ambiental, in: Revista Consulex, n. ${ }^{\circ}$ 2, ano 1, Fevereiro de 1997, pp. 53-55.
} 
conhecida ineficácia dos aparelhos de fiscalização do Estado"76.

Frente ao exposto, passe-se agora a apresentar o perfil do turismo no Distrito Federal, como forma de entender suas principais características.

${ }^{76}$ SPONHOLZ, O. L. Meio Ambiente - Dano e Responsabilidade Civil. São Paulo: RT, 2000, p. 153. 


\section{PERFIL DO TURISMO NO DISTRITO FEDERAL}

\subsection{Histórico}

Brasília, apesar de ser uma cidade jovem, traz preocupação quanto ao enorme fluxo migratório de trabalhadores de outros estados para sua periferia, atraídos pela possibilidade de melhoria de vida na capital. Isso porque, a construção da nova capital do Brasil, a partir de 1956, estimulou fortemente a migração de trabalhadores para o Distrito Federal. O objetivo geral e principal de construir Brasília para interiorizar as decisões nacionais e, com elas, povoar e desenvolver o Centro-Oeste, começa a ser realidade na medida em que se considera a capital consolidada e na proporção em que se verifica a ocupação de vastas porções do território periférico ao DF, principalmente no Estado de Goiás.

Tendo como atração, sobretudo o mercado de trabalho, levas de migrantes se deslocaram de diferentes pontos do país. Posteriormente, concomitantes com a transferência de funcionários, novos contingentes chegaram, tendo-se, por isso, dois tipos de crescimento: o planejado e o espontâneo. O ritmo de crescimento espontâneo excedeu às previsões, até mesmo à capacidade da cidade em absorvê-los. Assim, para fornecer domínio a esta população que buscava emprego urbano, novas localidades foram criadas na periferia, sendo alimentadas por correntes migratórias espontâneas. Aí reside a importância e a justificativa do estudo desenvolvido por SIQUEIRA \& LIMA (2003), posto que, se o turismo religioso se apresentar como um significativo gerador de emprego e renda, isso pode revelar uma importante tendência: a da polivalência das instituições religiosas, as quais ao mesmo tempo em que contribuem para o crescimento e o desenvolvimento da cidade, por meio de atividades relacionadas ao turismo, ampliam suas atividades e, conseqüentemente, aumentam a oferta de emprego e o nível de renda no DF.

Segundo o Brasília Convention \& Visitors Bureau, Brasília é a "capital mística” do país. Sua localização estratégica no Planalto Central, profetizada a mais de cem anos no sonho de Dom Bosco, esse misticismo foi acentuado por sua arquitetura e seu 
traçado Urbanístico. Documentário desenvolvido por KERN \& PIMENTEL (2001) e intitulado “Brasília Secreta”, busca estabelecer uma relação mística entre a Capital Federal e o Antigo Egito, não somente em seus aspectos místicos, mas também em razão das obras gigantescas (“faraônicas”). Daí porque SIQUEIRA \& LIMA (2003) assim se expressam:

\begin{abstract}
"Brasília, inaugurada em 1960, nasceu a partir de dois grandes mitos de criação: a cidade Utópica e a Terra prometida. O primeiro está inscrito no planejamento urbano e na arquitetura futurista do Plano Piloto. Os fundadores da cidade estavam imbuídos do sonho e da missão de inaugurar um novo tempo e uma nova civitas para o Brasil, fundada no belo, na igualdade e na universalidade"77.
\end{abstract}

Note-se, pelo trecho acima, a referência aos demais objetivos de Brasília, como cidade a "inaugurar um novo tempo e uma nova 'civitas' para o Brasil”, posto que a capital era parte da chamada "Marcha para o Oeste", em que se pretendia promover o maior povoamento e desenvolvimento das regiões Centro-Oeste e Norte. Os turistas se sentem seduzidos pelas muitas organizações esotéricas, filosóficas e religiosas que migraram para o planalto central. Estudos da SETUR-DF ${ }^{78}$ constatam que é cada vez maior o volume de pessoas que visitam o Templo da Boa Vontade, fazendo deste local o ponto turístico mais visitado de Brasília, sendo que, somente no ano de 2003, registrouse um total de 1.261 .097 visitas.

No contexto turístico do DF, Brasília tem o maior potencial, pois abriga a sede dos Três Poderes da República e seus belos monumentos arquitetônicos, bem como o moderno traçado urbanístico. Contudo, pode-se ainda destacar a Região Administrativa de Planaltina, que abriga a cidade histórica, fundada em 1790, e cuja maior representação histórica vem da /passagem da Missão Cruls em 1893. Tal Missão tinha o intuito de demarcar e explorar a região da futura capital do Brasil, e tem sua saga exposta no Museu Histórico de Planaltina (inaugurado em 22 de abril de 1974) ${ }^{79}$.

\footnotetext{
${ }^{77}$ SIQUEIRA, Deis \& LIMA Ricardo Barbosa de. "Sociologia das adesões: novas religiosidades e a busca místico-exotérica na capital do Brasil”. Rio de Janeiro: Garamond Vieira, 2003, pp. $28-29$.

${ }^{78}$ SETUR-DF. “Guia de visitações”. Brasília: SETUR, 2003.

${ }^{79}$ EMBRATUR. Inventário da Oferta Turística, 1992.
} 
Anos mais tarde, em 1922, ano do Centenário da Independência, a cidade de Planaltina recebeu a Pedra Fundamental, que servia para consolidar o interesse pela transferência da capital para o Planalto Central. Não bastasse o potencial histórico, Planaltina é um dos principais pólos de turismo rural e ecológico do DF, onde estão instaladas 08 propriedades rurais de grande significância para o turismo rural da capital, além de restaurantes de cozinha típica, pesque-pagues etc., e a Estação Ecológica de Águas Emendadas ${ }^{80}$.

Além de todo este potencial, destaca-se a comunidade mística, que por sua importância e sua dimensão social e religiosa, pode ser considerada como mais um potencial para a exploração turística na cidade de Planaltina, o que, caso seja bem dotada de infra-estrutura de apoio turístico ${ }^{81}$ poderá, sem dúvida, tornar-se importante pólo de turismo do DF. Desde a sua criação, como projeto urbanístico, Brasília carrega, todo um aspecto místico que, somado à sua exuberância monumental, traz um interessante atrativo àqueles que a visitam. Conforme explicam SIQUEIRA \& LIMA (2003):

\begin{abstract}
“Na capital e na região, há um numero cada vez maior de pessoas e de grupos que estão tentando construir uma nova consciência religiosa, ancorada na busca de auto-conhecimento e de autoaperfeiçoamento, na construção de uma nova visão holística do mundo, construída em torno da preparação para a nova visão holística do mundo, e construída em torno da preparação para a Nova Era ou Novo Milênio" ${ }^{\text {. }}$
\end{abstract}

O conhecido “sonho visão” de Dom Bosco, no qual foi previsto o surgimento de uma cidade, colocado de forma figurativa pelo religioso, como somado ao aspecto de ter sido concebido de maneira completa o projeto urbanístico, segundo Lúcio Costa, quando diz:

"Não pretendia competir e, na verdade, não concorro, apenas me desvencilho de uma solução possível, que não foi procurada, mas

\footnotetext{
${ }^{80}$ EMBRATUR. Inventário da Oferta Turística, 1992.

${ }^{81}$ Trata-se do conjunto de obras e instalações de estrutura física de base, que criam condições para o desenvolvimento de uma unidade turística, tais como sistema de transporte, comunicações e sérvios urbanos (água, luz, esgoto e limpeza pública). EMBRATUR. Inventário da Oferta Turística, 1992.

${ }^{82}$ SIQUEIRA \& LIMA, Op. Cit., p. 29.
} 
surgiu, por assim dizer, já pronta. Brasília nasceu de um gesto primário de quem assinala um lugar ou dele toma posse: dois eixos cruzando-se em ângulo reto. Ou seja, o próprio sinal da cruz",83.

Não bastassem esses dois importantes aspectos, de cunho místico, que envolvem a Capital Federal, fica também ainda mais forte esta característica ao se considerar que Dom Bosco, em um de seus sonhos, revelado em 30 de agosto de 1883, previu, no mesmo paralelo onde está construída Brasília, o local da Terra Prometida.

\subsection{Perfil social de Brasília}

Brasília se encaixa nesta lógica: é um aglomerado humano singular quando visto dentro da sociedade brasileira. Um espaço pensado, com funções principais predefinidas, implantado em área relativamente desocupada, sem barreira social que se contrapusesse ao projeto original. A decisão de construí-la guarda uma lógica que se respalda, à primeira vista, em pressupostos eleitorais, a partir de promessas de campanha para a Presidência da República nas eleições de 1955, quando se iria decidir a sucessão de um mito de nossa historia política, Getúlio Vargas, recém-falecido. Na essência, são questões de fundo que estão sendo redefinidas dentro da dinâmica social do país e Brasília é uma peça nesta engrenagem ${ }^{84}$.

Brasília surge neste imaginário em construção com uma perspectiva simbólica de conquista. NUNES argumenta que os discursos e as imagens criados em torno de Brasília apresentaram um peso decisivo no processo de resgate do imaginário da conquista e da fundação: Quando facetas do imaginário puderam se materializar nas imagens de conquista e de desbravamento próprias ao processo de transferência e de construção da nova capital, inserida numa mitologia desenvolvimentista que enxergava em novo país a partir de sua industrialização prevista no Plano de Metas, ou seja, uma sociedade em que as diferenças sociais estariam sendo ultrapassadas por um desenho urbano original. Assim, tanto os parlamentares favoráveis à proposta, quanto JK e os

\footnotetext{
${ }^{83}$ Idem, ibidem.

${ }^{84}$ NUNES, Brasilmar Ferreira. “Brasília: a fantasia corporificada”. Brasília: Paralelo 15, 2004, p. 56.
} 
propios arquitetos autores do projeto constroem um discurso nos limites do universo simbólico brasileiro, conferindo, um sentido não premeditado a Brasília; a construção da cidade passou, pouco a pouco, a ser a fundação da nação ${ }^{85}$.

O discurso fundador da nova capital, a reinvenção de suas origens fica sob a responsabilidade d um pequeno grupo da burocracia estatal que, diretamente interessado no projeto, responsabiliza-se por transformar o sonho em realidade. Em um país que as capitais caracterizam-se por transformar o sonho em realidade. Esta ameaça latente, de tempos em tempos, volta à cena. A resistência a uma possibilidade dessa natureza está na capacidade de o novo projeto corresponder aos sonhos dos que estariam por ele seduzidos ${ }^{86}$.

Em Brasília, mais uma vez, é a cidade capitalista por excelência que se apresenta que se apresenta. Justamente é essa "real” mobilidade que "para ocorrer basta nos empenharmos objetivamente para alcançá-la” (sic), que é um dos pilares de sustentação da lógica social existente. No fundo, há uma extrema rigidez na estrutura social da cidade sobretudo quando estamos refletindo sobre a mobilidade vertical, mas a possibilidade horizontal é um fato; é sobretudo ela que garante o mito fundador ${ }^{87}$.

O rápido e elevado crescimento populacional, trouxe a reboque enormes problemas consubstanciados nas carências em serviços coletivos, cuja oferta não conseguiu acompanhar o crescimento da demanda, de resto uma característica da urbanização brasileira que não se altera mesmo com um urbanismo minucioso, como é o caso de Brasília. Invasões de áreas públicas, até mesmo de mananciais preservados, aliados à expansão dos índices de violência e de criminalidade passaram a compor um cotidiano próximo ao das grandes cidades do país. As campanhas eleitorais - quando se explicitam plataformas de governo dos candidatos de diferentes correntes políticas refletem com precisão este fenômeno: entre as promessas de emprego, habitação, educação, controle de violência, Brasília é uma cidade típica de sociedade

\footnotetext{
${ }^{85}$ Idem, p. 76.

${ }^{86}$ Idem, p. 88.

${ }^{87}$ Idem, pp. 91-92.
} 
subdesenvolvida, mesmo se a imagem que passa ao país é a de “ilha da fantasia”88.

De fato, as teorias sobre as evidencias espaciais das desigualdades sociais e econômicas dentro do espaço urbano e seus efeitos sobre a ecologia urbana encontraram, em Brasília, uma concretude lapidar quando se analisa a espacialidade intra-urbana da renda ${ }^{89}$.

O grau de mobilidade e fluidez social é um excelente indicador de “justiça” para a sociedade. Se isolarmos o Plano Piloto percebemos que, em média, é uma área privilegiada em qualquer dimensão. Pode significar a aspiração máxima em termos de moradia e dar a sensação de área conservadora; talvez porque se aceite e se valorize a presença do estado, não havendo praticamente nenhum envolvimento direto dos moradores na gestão da cidade e paralelamente comungue por idéias mais flexíveis e inovadoras na esfera privada da vida ${ }^{90}$.

No geral, para o conjunto das cidades do país, o poder local prioriza seus investimentos urbanísticos nas áreas com populações de padrão médio e superior de renda. Isso se explica tanto por razões objetivas, no sentido de que os impostos locais são sistematicamente pagos por eles, como ainda por se tratar de áreas em que o padrão educacional é relativamente acima da média, havendo portanto um grau de consciência de direitos frente ao estado que facilita a explicitação de demanda junto ao poder local; são indivíduos e grupos com elevado poder político junto às administrações locais ${ }^{91}$.

Ora, a inexistência de relações de vizinhança questiona o conceito mesmo do urbanismo implantado e escancara uma característica da classe média que é exatamente a sua tendência ao isolamento, à auto-identificação narcísica que prescinde do outro para se identificar, como se não tivesse muita coisa a trocar, a somar com pessoas do mesmo ou de outros níveis sociais. O fenômeno é tão mais acirrado se considerarmos que as inter-relações com outros grupos sociais é praticamente inexistente pois o

\footnotetext{
${ }^{88}$ Idem, p. 99.

${ }^{89}$ Idem, p. 108.

${ }^{90}$ Idem, p. 138.

${ }^{91}$ Idem, p. 153.
} 
desenho do espaço urbano no Distrito Federal isola por classes de renda os grupos sociais, transformando as satélites mais longe do que os grande centros do país a milhares de quilômetros de distancia ${ }^{92}$.

\subsection{Perfil turístico de Brasília}

Conhecida em todo o mundo pela leveza de sua arquitetura e arrojo de seu traçado urbanístico, Brasília, com pouco mais de quatro décadas de existência, conseguiu obter não só o reconhecimento da UNESCO como "Patrimônio da Humanidade”, como também despertar o interesse de turistas de várias partes do planeta, que querem ver como é o dia-a-dia do centro das decisões nacionais ${ }^{93}$.

Mas não são só os perfis arquitetônico e urbanístico que vêm atraindo turistas, nacionais e estrangeiros. Em 43 anos, a cidade ganhou vida própria, deixou de ser um mero centro administrativo, viu sua população crescer em proporções inusitadas, criando vida noturna e opções de lazer que vão das manifestações artísticas (locais, nacionais e internacionais) até entretenimentos comunitários compatíveis com sua vocação de centro aglutinador das mais variadas culturas do Brasil e de outros países ${ }^{94}$.

Neste contexto, a cidade ganhou mais uma característica: hospedeira de convenções. Nos últimos anos, Brasília vem conquistando a preferência de vários segmentos da política e da economia para importantes encontros, o que acabou por obrigar a cidade a desenvolver tecnologia adequada para o setor hoteleiro e preparar-se diariamente para uma crescente movimentação turística ${ }^{95}$.

A capital federal dispõe vários hotéis sendo bem classificados pela Empresa Brasileira de Turismo (EMBRATUR - 2002), dos quais quatro são “cinco estrelas”, seis são “quatro estrelas”, 14 são "três estrelas”, sete são “duas estrelas” e três são "uma

\footnotetext{
92 Idem, p. 161.

${ }^{93}$ EMBRATUR. “Inventário da oferta turística”. Brasília: Embratur, 2004, p. 5.

${ }^{94}$ Idem, ibidem.

${ }^{95}$ Idem, p. 9.
} 
estrela”,

A oferta hoteleira nos últimos quatro anos mostra um crescimento de oito novos estabelecimentos, com 673 unidades hoteleiras, representando mais de 1.563 leitos. Até o final de 2000, sete novos hotéis se apresentaram em pleno funcionamento, acrescentando às estatísticas mais 3.020 leitos. Isto significa que os novos hotéis representarão, nesse período, um acréscimo de $27,7 \%$ na oferta hoteleira da cidade ${ }^{97}$.

Para que se tenha uma idéia do que isso representa, basta observar que os hotéis classificados pela EMBRATUR em Brasília registram em média 32 mil hóspedes por mês, período em que são gerados 80 mil pernoites mensais e 950 mil anuais. Os hotéis de Brasília registram uma média anual de ocupações da ordem de 50\%. A menor taxa média de ocupação (32,7\%) é verificada no mês de janeiro e a maior em agosto (55,2\%). A permanência média do turista, verificada nos últimos anos em Brasília, foi de 2,53 dias. Em todo o ano de 2000, porém, esta taxa subiu para 3,14 dias ${ }^{98}$.

Mesmo nos hotéis ainda em fase de classificação, é possível verificar o crescente interesse dos turistas por Brasília. Nestes estabelecimentos foram gerados 215.507 pernoites. A média de ocupação anual registrada foi de 60\%, superior em 39\% à média dos hotéis classificados pela EMBRATUR no mesmo período. Aqui, a permanência média do turista cresce bastante: 5,52 dias, ou seja, 85,2\% acima da permanência média nos hotéis classificados ${ }^{99}$.

Para se compreender este crescimento no setor turístico em uma cidade tão jovem é importante observar o fluxo de visitantes nos principais pontos turísticos e suas taxas anuais.

Brasília dispõe, hoje, de inúmeros pontos turísticos tradicionais, dentre os quais se destacam o Congresso Nacional, o Memorial JK, Museu do Catetinho, Museu

\footnotetext{
${ }^{96}$ Idem, p. 10.

${ }^{97}$ Idem, ibidem.

${ }^{98}$ Idem, p. 11.

${ }^{99}$ Idem, p. 12.
} 
Etnográfico, Museu de Artes e Tradições do Nordeste, os palácios da Alvorada, do Planalto, do Itamaraty, além da Torre de Televisão, Panteão da Pátria Tancredo Neves, Santuário Dom Bosco e o Templo da Legião da Boa Vontade (LBV), este, um campeão de visitações. O fluxo de visitantes àqueles pontos em 2000 chegou a 972.520 turistas nacionais e estrangeiros ${ }^{100}$.

No que tange às Agências de Turismo, segundo a Federação das Indústrias de Brasília (FIBRA - 2002) e da Secretaria de Turismo (SETUR/DF - 2003), Brasília tem hoje 312 agências de viagens registradas, mas apenas 14 praticam o chamado turismo receptivo e são elas responsáveis pelos índices acima. Até o final de 94, 237 agências de turismo e viagens operavam regularmente na capital. Segundo relatório de 2000, da EMBRATUR, 90\% das agências do Brasil trabalham exclusivamente com o turismo emissivo (que promove a saída temporária do cidadão de seu local de permanência). Em Brasília, 95\% delas são emissivas e $5 \%$ são receptivas ${ }^{101}$.

Mas a força do setor na cidade fez surgir 131 novas empresas nos últimos quatro anos, o que significa um crescimento de 72,3\% desses estabelecimentos. Há um curioso leque de interesses turísticos em Brasília, diferenciando o perfil de Brasília em relação a outros pontos de visitação do resto do país. Neste aspecto é interessante ver a característica do turista brasileiro e do estrangeiro na cidade ${ }^{102}$.

Os índices da SETUR/DF mostram que 58,27\% dos brasileiros vão à capital federal principalmente a negócios. Os eventos constituem a segunda maior motivação, apontada por $17,92 \%$ dos turistas brasileiros na média dos últimos quatro anos. O turismo de lazer aparece como principal motivo para 6,42\% dos turistas na média do mesmo período ${ }^{103}$.

Também é curioso notar que a média de idade dos turistas brasileiros nos 72 hotéis classificados pela EMBRATUR, no período de janeiro de 1991 a setembro de

\footnotetext{
${ }^{100}$ Idem, ibidem.

${ }^{101}$ Idem, p. 13.

${ }^{102}$ Idem, ibidem.

${ }^{103}$ Idem, p. 18.
} 
2002, é de $39 \operatorname{anos}^{104}$.

O poder aquisitivo dos que visitam a cidade anualmente também não é dos mais baixos, haja vista o tipo de transporte que utilizam para conhecer Brasília: 84,87\% dos brasileiros que chegam a capital utilizam o transporte aéreo, 10,75\% fazem uso de carro próprio, enquanto 4,62\% utilizam o ônibus como meio de transporte ${ }^{105}$.

Mais homens (81,22\%) que mulheres (18,78\%) visitam anualmente Brasília. Os principais estados emissores de turistas brasileiros a Brasília são, pela ordem, São Paulo, Rio de Janeiro, Minas Gerais, Goiás, Paraná, Rio Grande do Sul e Bahia ${ }^{106}$.

Os turistas de outros países que visitam Brasília têm como motivação principal o turismo de lazer. Eles totalizam 58,25\% dos visitantes, em média. Outros 26,94\% dos estrangeiros visitam a capital a negócios. O turismo de eventos, que está em franco crescimento nesses últimos quatro anos, trouxe $7,53 \%$ de estrangeiros em relação ao total dos visitantes que chegam à cidade pelo mesmo motivo ${ }^{107}$.

Os estrangeiros utilizam prioritariamente o avião como meio de transporte, com média de 95,55\%. O ônibus é utilizado por 9,30\% e o automóvel por outros 1,35\% dos turistas internacionais. Em média, quase $80 \%$ dos estrangeiros que se hospedam nos hotéis classificados pela EMBRATUR são do sexo masculino e 20,12\% são do sexo feminino. A média de idade desse turista na capital é de 42 anos. Os principais países emissores de turistas estrangeiros para Brasília são Estados Unidos, França, Itália, Alemanha, Espanha e Argentina, nessa ordem ${ }^{108}$.

Sede administrativa do país, Brasília foi inaugurada pelo presidente Juscelino Kubitscheck de Oliveira em 21 de abril de 1960, após 1.000 dias de construção. Em 1987, foi tombada pela UNESCO como patrimônio cultural da humanidade. A cidade fica na região Centro-Oeste, entre os paralelos 15,30’,00” e 16,03’06” e os rio Preto, a

\footnotetext{
${ }^{104}$ Idem, ibidem.

${ }^{105}$ Idem, p. 19.

${ }^{106}$ Idem, p. 20.

${ }^{107}$ Idem, ibidem.

${ }^{108}$ Idem, p. 21.
} 
leste, e Descoberto, a oeste. Tem uma área de $5.782 \mathrm{Km}^{2}$ e uma população de mais de dois milhões de habitantes. Quem nasce em Brasília é brasiliense, ou candango ${ }^{109}$.

A capital do Brasil está a uma altitude média de 1.100 metros e tem uma densidade demográfica de 299,2 habitantes por quilômetro quadrado. Tem clima tropical de savana e temperado chuvoso. A temperatura média anual é de 20,5 graus e a umidade relativa do ar chega a $25 \%$ no inverno e $68 \%$ no verão. Brasília, onde se localiza a cidade, possui 19 regiões administrativas. Estas três horas a menos em relação ao meridiano de Greenwich ${ }^{110}$.

Brasília propicia um lazer típico de cidade do interior. Assim, são possíveis passeios de bicicleta pelo Parque da Cidade onde se localiza um dos mais importantes pontos de preservação ambiental, passeio de “pedalinho" e prática de Cooper em contato direto com a natureza nos locais especialmente destinados para este fim.

Uma das mais atraentes diversões que vem conquistando o coração dos turistas da capital é o passeio de ultraleve. Nele, o turista, nacional ou estrangeiro, também pode viver o seu sonho de Ícaro, num vôo de dez minutos, em que se pode observar, do alto (mas a baixa altitude) as maravilhas construídas por Oscar Niemeyer e Lúcio costa, os point tour e toda a beleza natural do lugar ${ }^{111}$.

Mas também há o passeio aéreo coletivo. A capacidade do táxi aéreo Fly-Fast S/A (avião Sêneca) é de cinco pessoas. O vôo tem duração de 20 minutos e pode ser solicitado em qualquer horário, inclusive à noite. Neste caso, pode-se constatar, quanto à iluminação, se de fato há, como dizem alguns, semelhanças entre Brasília e Paris ${ }^{112}$.

Em meio a este misto de cidade grande e lugarejo interiorano pode-se reunir, em um só lugar, executivos de várias partes do mundo. A cidade reservou quatro grandes espaços para a realização de encontros e convenções. São eles o Centro de Convenções

\footnotetext{
${ }^{109}$ Idem, p. 22.

${ }^{110}$ Idem, p. 23.

${ }^{111}$ Idem, p. 25.

${ }^{112}$ Idem, ibidem.
} 
Dr. Ulisses Guimarães; Academia de Tênis de Brasília; Instituto Israel Pinheiro; e o Pavilhão de Feiras e Exposições do Parque da Cidade ${ }^{113}$.

Para os turistas estrangeiros, não há dificuldades para a troca de moeda. São 38 instituições, financeiras e de turismo, habilitadas para fazer a troca de qualquer moeda do mundo.

Conforme explicam EMBRATUR ${ }^{114}$, à noite, o turista dispõe de várias casas de espetáculos, sendo uma das mais importante delas o Teatro Nacional Cláudio Santoro, que abriga três confortáveis salas (Villa Lobos, Martins Penna e Alberto Nepomuceno). Antes ou depois de uma peça ou concerto, pode ser interessante uma visita a qualquer dos um dos shopping-centers de Brasília ou das Cidades Satélites (Alameda, Gilberto Salomão, Conjunto Nacional, Park Shopping, Super Center Venâncio 2000, Super Center Venâncio 3000, Liberty Mall, Brasília Shopping, Taguatinga Shopping e Pátio Brasil) $)^{115}$.

A história da cidade e a memória nacional estão guardadas em 24 museus, sendo os mais visitados o Memorial JK, o Catetinho - primeira residência oficial do presidente da Republica, Juscelino Kubitschek, o construtor de Brasília -, o Banco Central, o Museu Vivo da Memória Candanga e o Museu de Arte e Tradição do Nordeste ${ }^{116}$.

Brasília é também conhecida como uma cidade mística. Ela reúne uma infinidade de templos de diversas seitas e religiões, de católicos e protestantes a seitas orientais, passando por cultos africanos e esotéricos. Neste plano do traço de Brasília, o turista pode visitar 18 templos principais, desde a Catedral Metropolitana, um verdadeiro cartão de visitas com linhas arquitetônicas concebidas pelo gênio Niemeyer, igrejas evangélicas, templos da ortodoxia e os templos: Budista da Terra Pura, da

\footnotetext{
${ }^{113}$ Idem, p. 26.

${ }^{114}$ Idem, p. 30.

115 Para os turistas que desejam obter mais informações sobre a cidade, existem alguns postos de informações turísticas. Os mais importantes são: Aeroporto Internacional de Brasília (de segunda a sextafeira, das 8 às 19 horas e sábados e domingos, das 9 às 20 horas); o Centro de Atendimento ao Turista, na Praça dos Três Poderes (de segunda a sexta, das 9 às 18 horas e sábados e domingos, das 9 às 19 horas); a Secretaria de Turismo de Brasília (de segunda a sexta-feira, das 13 às 19 horas); e o Catetinho, de terça a domingo, das 9 às 17 horas).

${ }^{116}$ Idem, p. 31.
} 
Seicho-no-iê, e da Legião da Boa Vontade, onde recentemente foi inaugurado o Parlamento Mundial da Boa Vontade, de tendência ecumênica ${ }^{117}$.

Mais de dez instituições ecológicas têm sede ou filiais em Brasília. Por meio delas pode-se obter informações sobre o meio ambiente de Brasília e os números dos “telefones verdes” para visitações e passeios ecológicos na cidade ou em sua periferia. Uma boa sugestão é a Curadoria do Meio Ambiente, a Secretaria de Meio Ambiente, Ciência e Tecnologia (SEMATEC), Polícia Florestal (PF) e o Instituto Brasileiro do Meio Ambiente (IBAMA), além de organizações não-governamentais, como as fundações Mata Virgem e Pro-Natureza ${ }^{118}$.

Como se vê, Brasília e sua Região do Entorno possuem considerável potencial de mercado para a exploração de atividades turísticas sustentáveis, e isso é o que se buscou valorizar por meio deste trabalho, acreditando-se que é possível desenvolver empreendimentos ecoturísticos que, ao mesmo tempo em que concorram para a dinamização da economia local, garantem um turismo menos destrutivo para o ecossistema da região, ajudando, ainda, na sua maior divulgação entre os turistas de todo o país.

Dessa forma, tendo sido apresentadas neste capítulo, as principais características do turismo no Distrito Federal, passe-se, no capítulo seguinte, a metodologia, a tabulação e a análise de dados decorrente da pesquisa de campo, cujos resultados orientaram a formação dos roteiros que serão oferecidos aos turistas que visitarem Brasília.

${ }^{117}$ Idem, p. 32.
${ }^{118}$ Idem, p. 35. 


\section{PESQUISA DE CAMPO}

\subsection{Metodologia da pesquisa}

Para esse estudo, foram aplicados questionários (modelo em anexo) junto a funcionários da recepção e agências de viagens localizadas em hotéis localizados em Brasília, estabelecimentos estes escolhidos aleatoriamente no universo pesquisa, formado a partir dos empreendimentos abaixo relacionados. No Setor Hoteleiro Norte, tem-se os seguintes hotéis ${ }^{119}$ :

\begin{tabular}{|c|c|c|c|}
\hline Hotel & Classificação & Telefone & Fax \\
\hline Eron Hotel & & $329-4000$ & 326-2698 \\
\hline Torre Palace Hotel & & $328-5554$ & $326-1042$ \\
\hline Garvey Park Hotel & & $328-9800$ & $326-4170$ \\
\hline Metropolitan Flat & & 327-3939 & 327-3938 \\
\hline Kubitschek Plaza & & 329-3333 & $328-9366$ \\
\hline Manhattan Flat & & $319-3060$ & $328-5685$ \\
\hline Hotel Casablanca & & $328-8586$ & $328-8273$ \\
\hline Bittar Plaza Hotel & & $328-7077$ & $328-7077$ \\
\hline Mirage Hotel & & $328-7150$ & $328-7150$ \\
\hline
\end{tabular}

No Setor Hoteleiro Sul, tem-se os seguintes hotéis ${ }^{120}$ :

\begin{tabular}{|c|c|c|c|}
\hline Hotel & Classificação & Telefone & Fax \\
\hline St. Paul & & $321-6688$ & 224-3935 \\
\hline Bonaparte Hotel & & $322-2288$ & $322-9092$ \\
\hline Alvorada Hotel & & $225-3050$ & $225-3130$ \\
\hline Hotel das Américas & & $321-3355$ & $321-1972$ \\
\hline Bristol & & $321-6162$ & $321-2690$ \\
\hline Hotel das Nações & & $322-8050$ & $225-7722$ \\
\hline San Marco & & $321-8484$ & 223-6552 \\
\hline Carlton Hotel & & $224-8819$ & 226-8109 \\
\hline Naoum Plaza & & $322-4545$ & $322-4949$ \\
\hline Phenícia & & $321-4342$ & $225-1406$ \\
\hline Hotel Nacional & & $321-7575$ & 223-9213 \\
\hline Planalto & & $322-1828$ & $225-8050$ \\
\hline Econotel & & $321-7337$ & - \\
\hline
\end{tabular}

\footnotetext{
${ }^{119}$ Fonte: www.viaecologica.com.br/brasilia.jpg (acesso em 26.06.2004).

${ }^{120}$ Fonte: www.viaecologica.com.br/brasilia.jpg (acesso em 26.06.2004).
} 
Conforme explicam OCTAVIAN, PAULESCU e MUNIZ ${ }^{121}$, o universo da pesquisa refere-se ao grupo, população-alvo, local ou área, precisando ser caracterizado e identificado segundo uma ou mais referências, de forma a distingui-lo de um determinado contexto. Especificamente no caso desse estudo, o universo da pesquisa foi composto pelos profissionais da recepção e de agências de viagem localizadas em estabelecimentos hoteleiros de Brasília (Setor Hoteleiro Norte e Setor Hoteleiro Sul).

Segundo VERGARA ${ }^{122}$, universo é o conjunto de elementos que possuem determinadas características. O universo da pesquisa recai e corresponde a todos que atuam em dado universo. Conforme OCTAVIAN, PAULESCU e MUNIZ ${ }^{123}$, universo ou população é "um conjunto definido de elementos que possuem determinadas características”. Para essa pesquisa, o universo foi composto por 22 estabelecimentos hoteleiros de Brasília (Setor Hoteleiro Norte e Setor Hoteleiro Sul), dentre os quais se retirou a amostra pesquisada. Por sua vez, a amostra, com base nos cálculos de VIEGAS $^{124}$, para populações finitas (com menos de 100.000 indivíduos), distribuída em locais diversos, e que dificultam a investigação, considerando os seguintes parâmetros de pesquisa social, é assim calculada:

- $\quad$ tamanho da população $(N)$ : 22 elementos;

- $\quad e=$ nível de confiança: $90 \%$;

- SPLIT (proporção de indivíduos com a característica de interesse [p e q]: $50 \%$. Níveis de confiança por unidades de desvios padrões ${ }^{125}$.

Tem-se que o Desvio Padrão $(\sigma)$ a ser utilizado é $=2, N$ é o tamanho da população e “n” é o tamanho da amostra:

\footnotetext{
${ }^{121}$ OCTAVIAN, Rosiu Ovidiu Petra; PAULESCU, Doina; MUNIZ, Adir Jaime de Oliveira. Normas para apresentação do relatório final do estágio profissional curricular supervisionado - EPCS. Brasília: UniCEUB, 2002, p. 26.

${ }^{122}$ VERGARA, Sylvia Constant. Projetos e relatórios de pesquisa em administração. 2. ed. São Paulo: Atlas, 1998, p. 45.

${ }^{123}$ OCTAVIAN, Rosiu Ovidiu Petra; PAULESCU, Doina; MUNIZ, Adir Jaime de Oliveira. Normas para apresentação do relatório final do estágio profissional curricular supervisionado - EPCS. Brasília: UniCEUB, 2002, p. 29.

${ }^{124}$ VIEGAS, Waldyr. Fundamentos de metodologia científica. Brasília: Universidade de Brasília, 2000, p. 142.

${ }^{125}$ Idem, ibidem.
} 


$$
\begin{aligned}
& n=\frac{\sigma^{2} \cdot p \cdot q \cdot N}{e^{2}(N-1)+\sigma^{2} \cdot p \cdot q} \therefore n=\frac{2^{2} \cdot 50 \cdot 50 \cdot 22}{10^{2}(22-1)+2^{2} \cdot 50 \cdot 50} \therefore \\
& n=\frac{220.000}{100 \cdot 21+4 \cdot 50 \cdot 50} \therefore n=\frac{220.000}{12.100}=18,18 \cong 18
\end{aligned}
$$

Logo, o tamanho mínimo da amostra é de 18, daí ter-se optado por distribuir questionários para 18 indivíduos em um universo de 22. Com isso, foram desenvolvidos e devidamente aplicados 18 questionários, entre os dias 12 e 13 de julho de 2004, representando 81,82\% do universo pesquisado, número com o qual se trabalhou, posto que, desta forma, garante-se indiscutivelmente a significância estatística mínima estabelecida pela fórmula de VIEGAS ${ }^{126}$, que de, pelo menos, $25 \%$.

Dentre os estabelecimentos que compunham o universo da pesquisa, os 18 que formaram a amostra são: Metropolitan Flat, Kubitscheck Plaza, Bonaparte Hotel, San Marco, Carlton Hotel, Naoum Plaza e Hotel Nacional (5 Estrelas); Phenícia, St. Paul, Manhattan Flat, Torre Palace Hotel e Eron Hotel (4 Estrelas); Bittar Plaza Hotel, Alvorada Hotel e Hotel das Américas (3 Estrelas); além das agências de viagem: Virtual Turismo (Grand Bittar), Brasília Air (Hotel Nacional) e Class Club (Blue Tree Park), tendo sido aplicado somente um questionário em cada um dos estabelecimentos aqui mencionados, junto a funcionários da recepção e agentes de viagem.

Um pré-teste foi aplicado para testar o grau de compreensão do questionário. A tabulação indicou não haver necessidade de corrigir ou substituir qualquer questão, pois nenhuma das alternativas apresentadas obteve percentual de rejeição igual ou superior a 30\%. O pré-teste (Anexo I) foi composto por 6 questões, tendo sido aplicado entre os dias 12 e 13 de julho de 2004, para 18 pessoas, conforme metodologia sugerida por MUCHIELLE ${ }^{127}$, escolhidas aleatoriamente entre os profissionais da recepção e de agências de viagem localizadas nos estabelecimentos hoteleiros pesquisados.

\footnotetext{
${ }^{126}$ VIEGAS, Waldyr. Fundamentos de metodologia científica. Brasília: Universidade de Brasília, 2000, p. 142.

${ }^{127}$ Apud VIEGAS, idem, ibidem.
} 
Conforme OCTAVIAN, PAULESCU e MUNIZ ${ }^{128}$, a técnica de amostragem aqui utilizada é a probabilística, resultado de cálculos estatísticos, caracterizada pela possibilidade de que cada elemento da população possa ser selecionado e estar representado em uma amostra. A técnica de amostragem utilizada foi a "aleatória simples” para a aplicação de questionários a uma amostra da população do universo de profissionais da recepção e de agências de viagem localizadas nos estabelecimentos hoteleiros. Tendo aqui sido explicados os objetivos e demais aspectos que caracterizam a razão da elaboração do presente trabalho, no próximo capítulo serão apresentados os resultados e análises da pesquisa. Dentre as principais variáveis, este estudo considerou:

a) tempo de permanência do turista - ocorrência de hóspedes que permanecem em Brasília por prazo igual ou inferior a dois dias;

b) demanda por turismo alternativo - ocorrência de hóspedes que buscam programação turística alternativa;

c) duração do programa turístico - ocorrência de hóspedes que buscam programação turística de curto prazo;

d) demanda por ecoturismo - ocorrência de hóspedes que busca programação turística voltada para atividades ecológicas;

e) demanda por atividades na Região do Entorno do DF - ocorrência de formação de pequenos grupos de hóspedes que desejam visitar a Região do Entorno do Distrito Federal.

Como instrumentos de pesquisa, além da consulta bibliográfica, esse estudo fez uso da distribuição, tabulação, análise e exposição gráfica de dados, oriundos da aplicação de questionários aplicados junto aos profissionais da recepção e de agências de viagem localizadas nos estabelecimentos hoteleiros.

Então, após terem sido descritos os principais procedimentos metodológicos adotados na estruturação deste trabalho, passa-se, no próximo item, a expor e analisar os dados oriundos da pesquisa de campo.

\footnotetext{
${ }^{128}$ OCTAVIAN, Rosiu Ovidiu Petra; PAULESCU, Doina; MUNIZ, Adir Jaime de Oliveira. Normas para apresentação do relatório final do estágio profissional curricular supervisionado - EPCS. Brasília: UniCEUB, 2002, p. 26.
} 


\subsection{Apresentação dos dados da pesquisa}

Nesse item, os dados da pesquisa são apresentados na forma de tabelas e gráficos, desenvolvidos por meio do software MS Excel for Windows (versão XP), de modo a propiciar a visualização e o fácil entendimento das informações coletadas, as quais servirão de base para a construção do roteiro turístico voltado a pequenos grupos de visitantes que, estando em Brasília, buscam programação alternativa, relacionada a turismo ecológico.

Tabela 1 - Brasília - Quanto à freqüência de hóspedes que permanecem em Brasília por prazo igual ou inferior a dois dias - 2004 .

\begin{tabular}{l|r|r}
\hline & Qtd. & \multicolumn{1}{c}{$\%$} \\
\hline (a) Sim. & 18 & 100,00 \\
\hline (b) Não. & 0 & 0,00 \\
\hline Total & 18 & 100,00 \\
\hline
\end{tabular}

Fonte: Pesquisa desenvolvida por Ricardo de Albuquerque Assis Republicano, em julho de 2004.

Gráfico 1 - Brasília - Quanto à freqüência de hóspedes que permanecem em Brasília por prazo igual ou inferior a dois dias - 2004.

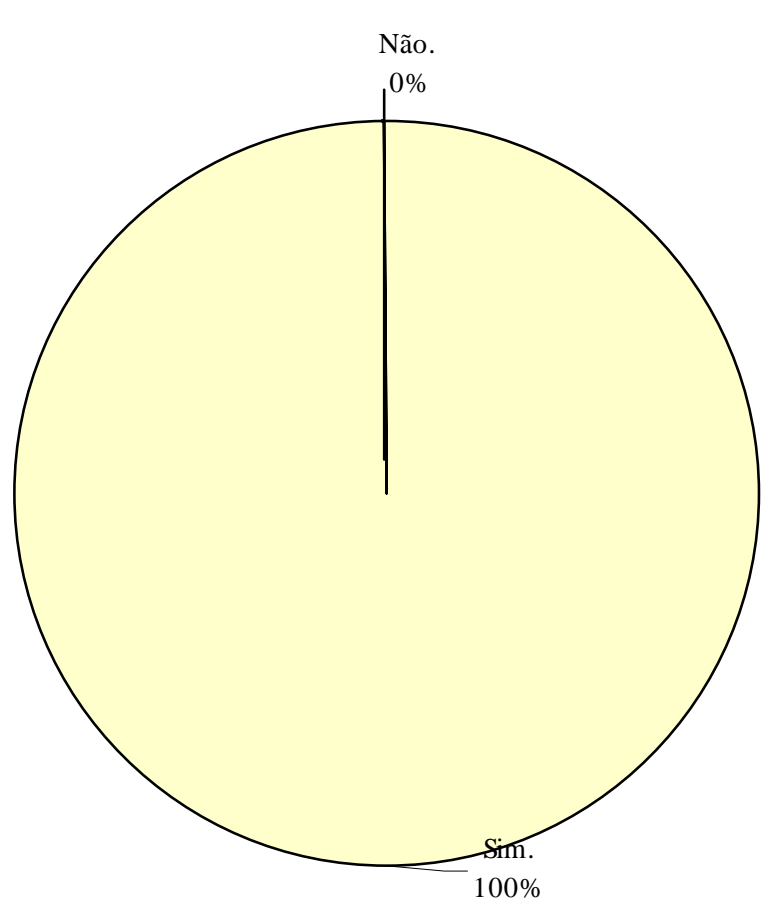

Fonte: Pesquisa desenvolvida por Ricardo de Albuquerque Assis Republicano, em julho de 2004. 
A Tabela 1 e o Gráfico 1, apresentados na página anterior, que analisaram a variável "tempo de permanência do turista", revelam que, entre os respondentes (recepcionistas de hotel e agentes de viagem), é unânime (100\%) a afirmação de que existem hóspedes cujo “tempo de permanência” em Brasília é de, no máximo, dois dias.

Tabela 2 - Brasília - Quanto à freqüência de hóspedes que buscam programação turística alternativa - 2004.

\begin{tabular}{l|r|r}
\hline & Qtd. & \multicolumn{1}{c}{$\%$} \\
\hline (a) Sim. & 7 & 38,89 \\
\hline (b) Não. & 11 & 61,11 \\
\hline Total & 18 & 100,00 \\
\hline
\end{tabular}

Fonte: Pesquisa desenvolvida por Ricardo de Albuquerque Assis Republicano, em julho de 2004.

Gráfico 2 - Brasília - Quanto à freqüência de hóspedes que buscam programação turística alternativa - 2004.

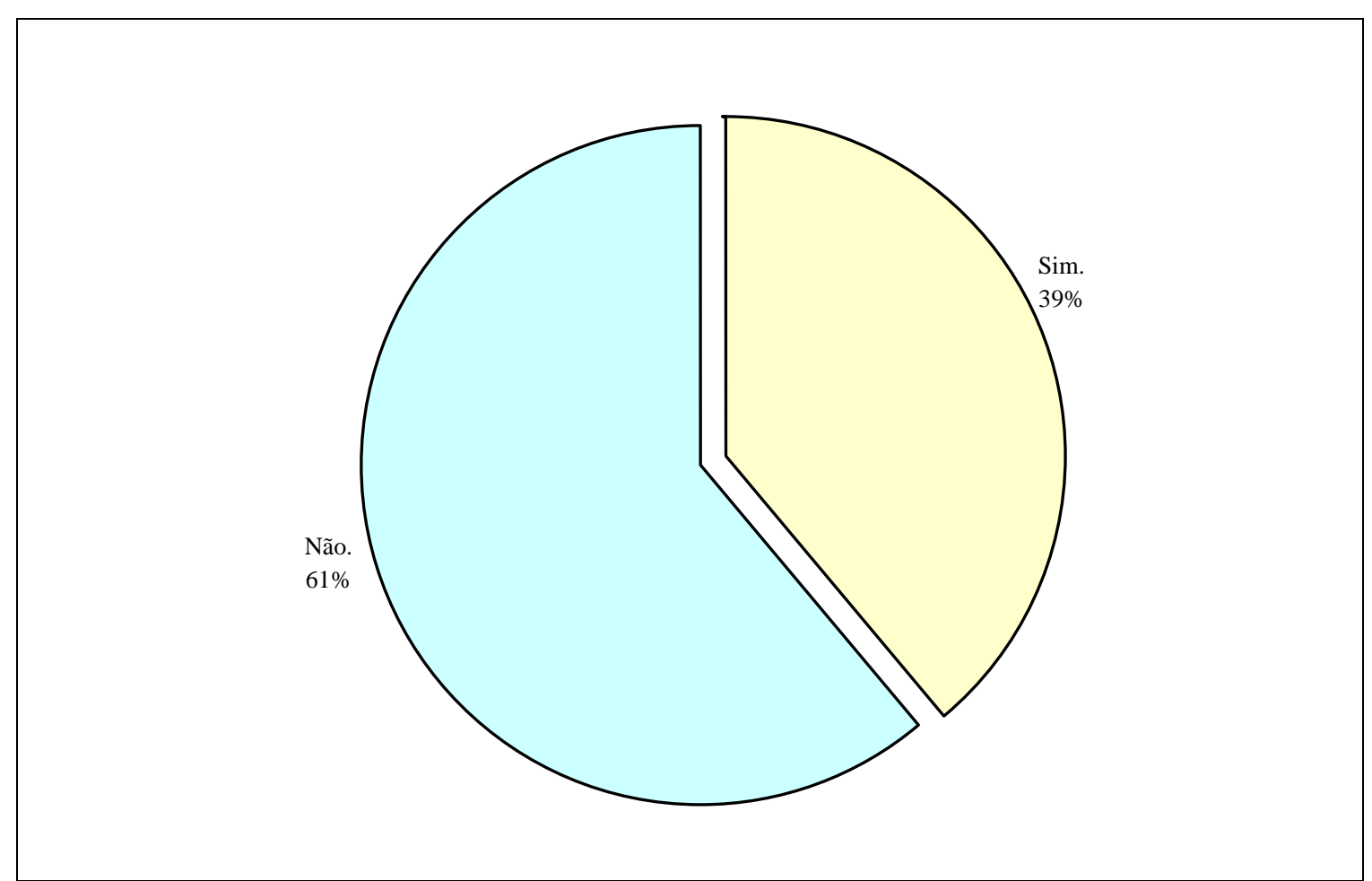

Fonte: Pesquisa desenvolvida por Ricardo de Albuquerque Assis Republicano, em julho de 2004.

Já a Tabela 2 e o Gráfico 2, acima expostos, cujo objetivo foi analisar a variável “demanda por turismo alternativo”, mostram que tal procura é negada por 61\% dos respondentes; sendo confirmada por 39\% do público pesquisado. 
Tabela 3 - Brasília - Quanto à freqüência de hóspedes que procuram programação turística de curta duração (máximo 2 dias) - 2004.

\begin{tabular}{l|r|r}
\hline & Qtd. & \multicolumn{1}{c}{$\%$} \\
\hline (a) Sim. & 15 & 83,00 \\
\hline (b) Não. & 3 & 17,00 \\
\hline Total & 18 & 100,00 \\
\hline
\end{tabular}

Fonte: Pesquisa desenvolvida por Ricardo de Albuquerque Assis Republicano, em julho de 2004.

Gráfico 3 - Brasília - Quanto à freqüência de hóspedes que procuram programação turística de curta duração (máximo 2 dias) - 2004.

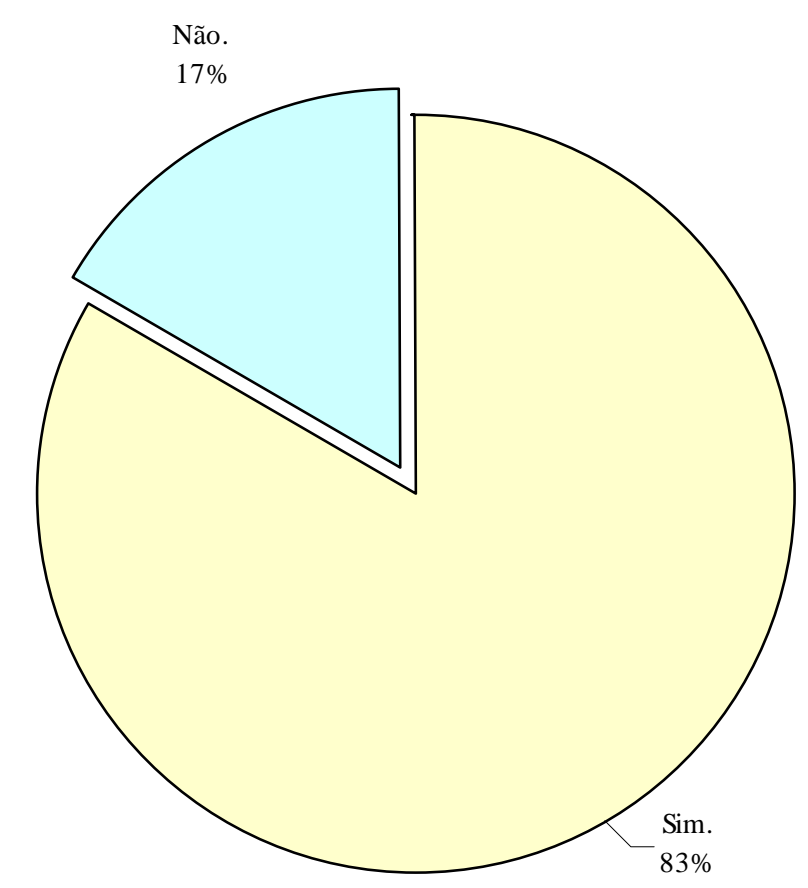

Fonte: Pesquisa desenvolvida por Ricardo de Albuquerque Assis Republicano, em julho de 2004.

Por sua vez, a Tabela 3 e o Gráfico 3, apresentados acima, cujo objetivo era mensurar a variável “duração do programa turístico”, mostram que, segundo 83\% os respondentes, há turistas demandando por programas com duração de até no máximo dois dias; ao passo que, na visão de $17 \%$ do público pesquisado a duração máxima de dois dias não se constitui realmente o tempo médio desejado pelos visitantes que se hospedam no Distrito Federal.

Não obstante, a Tabela 4 e o Gráfico 4, expostos na próxima página, cujo objetivo principal foi avaliar a variável “demanda por ecoturismo”, mostram que, na 
opinião de 78\% do público pesquisado, não há, entre os turistas, demanda por atividades turísticas direcionadas à ecologia; enquanto que, conforme $22 \%$ dos respondentes, existe, com freqüência, demanda por atividades turísticas que priorizem o ecoturismo.

Tabela 4 - Brasília - Quanto à freqüência de hóspedes que procuram atividades turísticas direcionadas à ecologia - 2004.

\begin{tabular}{l|r|r}
\hline & Qtd. & \multicolumn{1}{c}{$\%$} \\
\hline (a) Sim. & 4 & 22,00 \\
\hline (b) Não. & 14 & 78,00 \\
\hline Total & 18 & 100,00 \\
\hline
\end{tabular}

Fonte: Pesquisa desenvolvida por Ricardo de Albuquerque Assis Republicano, em julho de 2004.

Gráfico 4 - Brasília - Quanto à freqüência de hóspedes que procuram atividades turísticas direcionadas à ecologia - 2004.

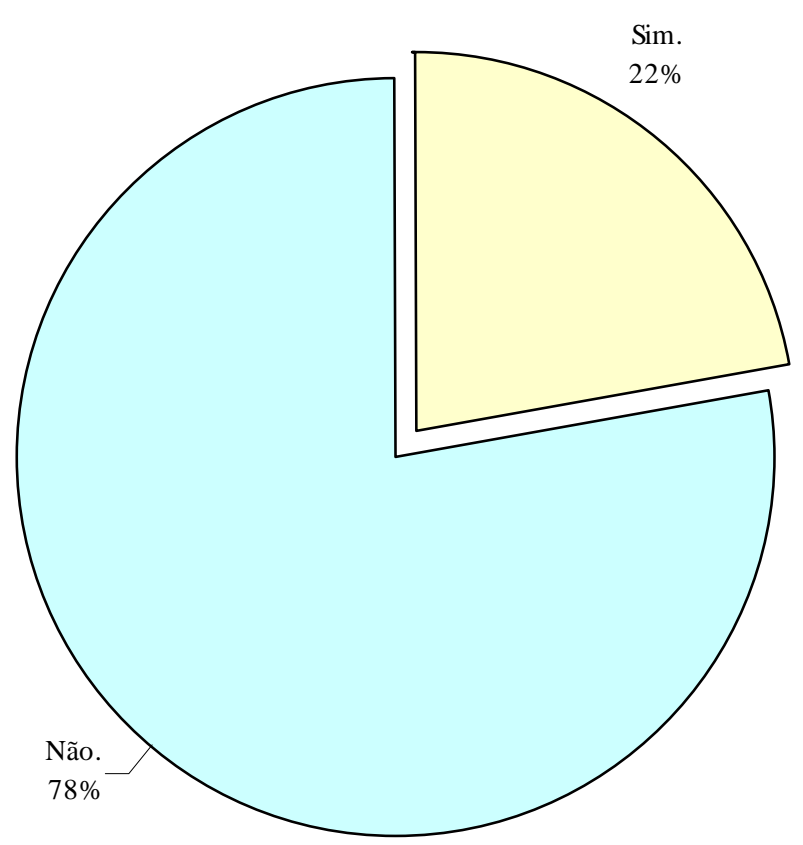

Fonte: Pesquisa desenvolvida por Ricardo de Albuquerque Assis Republicano, em julho de 2004.

Por fim, a Tabela 5 e o Gráfico 5, apresentados na página seguinte, cuja meta maior era analisar a variável “demanda por atividades na Região do Entorno do DF”, mostram que, na opinião de $89 \%$ do público pesquisado, não há, entre os turistas, demanda por atividades turísticas que sejam desenvolvidas na Região do Entorno do Distrito Federal; no entanto, segundo os demais 11\% dos respondentes, existe, de forma 
significativa, demanda por atividades turísticas que sejam desenvolvidas na Região do Entorno do Distrito Federal.

Tabela 5 - Brasília - Quanto à freqüência de hóspedes que buscam programação turística voltada para a Região do Entorno do DF - 2004.

\begin{tabular}{l|r|r}
\hline & Qtd. & \multicolumn{1}{c}{$\%$} \\
\hline (a) Sim. & 2 & 11,11 \\
\hline (b) Não. & 16 & 88,89 \\
\hline Total & 18 & 100,00 \\
\hline
\end{tabular}

Fonte: Pesquisa desenvolvida por Ricardo de Albuquerque Assis Republicano, em julho de 2004.

Gráfico 5 - Brasília - Quanto à freqüência de hóspedes que buscam programação turística voltada para a Região do Entorno do DF - 2004.

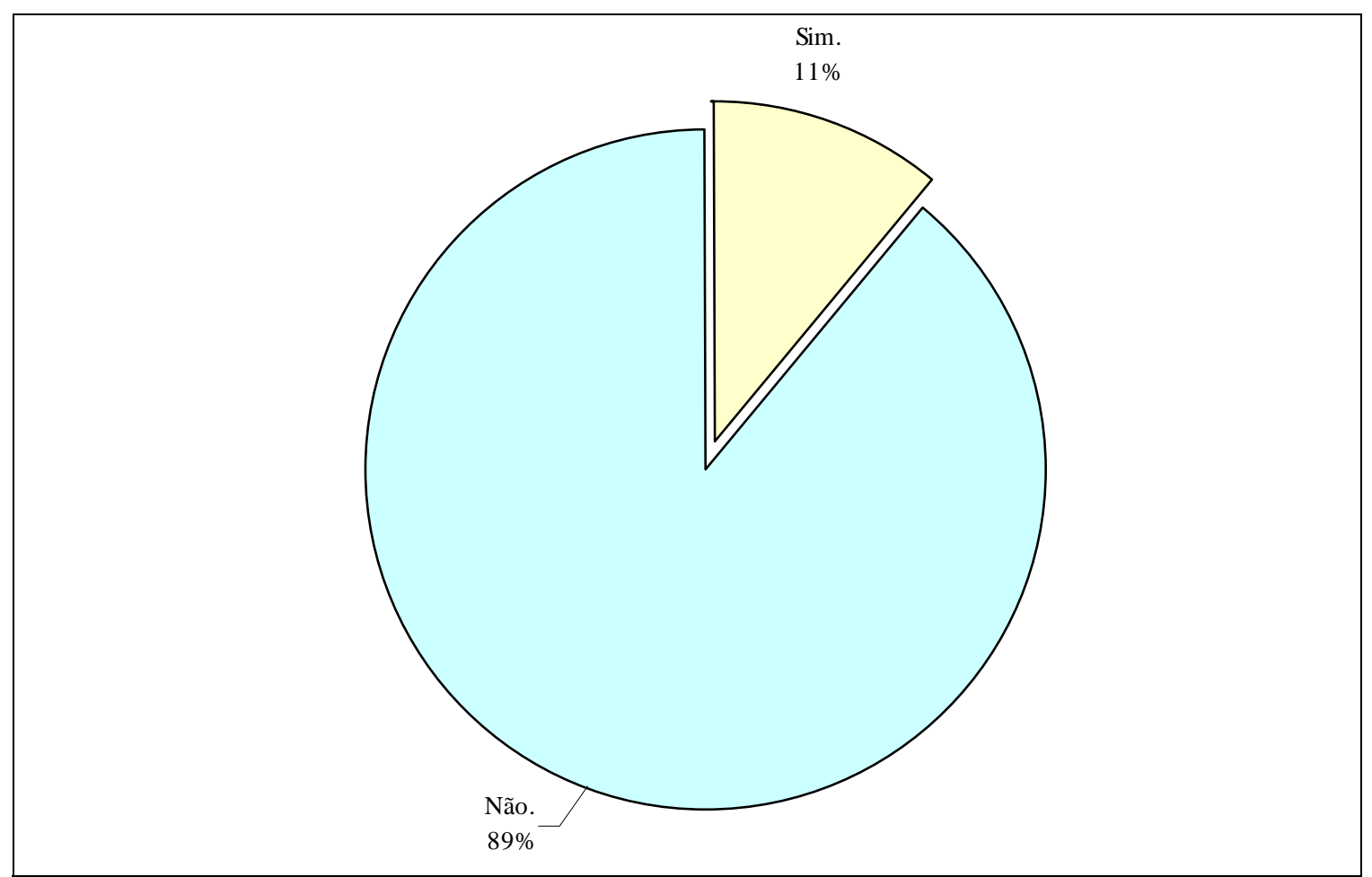

Fonte: Pesquisa desenvolvida por Ricardo de Albuquerque Assis Republicano, em julho de 2004.

Dessa forma afirma-se que, tendo aqui sido expostos, na forma gráfica, os dados da pesquisa de campo desenvolvida junto aos estabelecimentos hoteleiros e suas respectivas agências de viagens, passa-se, no próximo item, a analisar os resultados aqui apresentados. 


\subsection{Análise dos dados da pesquisa}

A pesquisa de campo revelou alguns dados importantes acerca do perfil da demanda exercida pelos turistas que se hospedam no Distrito Federal, demonstrando que, em geral, a maioria deles permanece (“tempo de permanência”) em Brasília por, no máximo, dois dias.

Outro importante fator diz respeito a que, no que tange à “demanda por turismo alternativo”, tal variável foi confirmada por 39\% do público pesquisado, mostrando que há potencial mercado para as modalidades de turismo ditas “não convencionais”, tais como o turismo de aventura, o turismo ecológico, entre outros. Ressalta-se que este percentual, embora não represente a opinião da maioria dos respondentes, é o que interessa para esse estudo, já que o que se busca é justamente uma opção diferente do turismo convencional, posto que as modalidades que aí inclusas apresentam um menor caráter de sustentabilidade.

Cabe também dizer que, em relação à “duração do programa turístico”, a pesquisa mostrou que, segundo 83\% dos respondentes, a duração máxima de dois dias se constitui o tempo médio desejado pelos visitantes que se hospedam no Distrito Federal. Esse curto espaço de tempo pode ser ideal para programas de baixo custo ou, ainda, para programas direcionados a pequenos grupos de visitantes.

Por sua vez, em relação à variável “demanda por ecoturismo”, a pesquisa revelou que, conforme $22 \%$ dos respondentes, existe, com freqüência, demanda por atividades turísticas que priorizem o ecoturismo. Essa informação, quando combinada com a análise da variável "demanda por turismo alternativo", serve para indicar que modalidade alternativa de turismo deverá ser priorizada na estruturação de programas turísticos, reduzindo-se assim o leque de possibilidades. Novamente destaca-se que esse percentual (22\%) é o que interessa para esse estudo. Além de se tratar de número a ser considerado (entre um quarto e um quinto da amostra), representa o contingente de pessoas que buscam atividades turísticas que podem ser caracterizadas como “sustentáveis". 
Por fim, no que concerne à variável “demanda por atividades na Região do Entorno do DF", a pesquisa mostrou que, segundo $11 \%$ dos respondentes, existe demanda por atividades turísticas que sejam desenvolvidas na Região do Entorno do Distrito Federal. Quanto ao percentual em si, acredita-se que sua baixa representatividade se deve ao fato de existir pouco trabalho de marketing relacionado às possíveis atividades turísticas na Região do Entorno do DF. Contudo, como se procura aqui desenvolver um ecoturismo sustentável, considerou-se esse percentual satisfatório, pois pode propiciar uma evolução do turismo local em níveis menos destrutivos.

Esse percentual, que para esse estudo é considerado “ideal”, é justamente o que motiva esse trabalho, pois, caso houvesse um percentual muito elevado de procura por atividades turísticas na Região do Entorno do DF, o trabalho teria outro enfoque, provavelmente buscando minimizar os efeitos devastadores da atividade turística de massa.

Daí se poder afirmar que, os pacotes turísticos que se pretende oferecer aos turistas que visitam o DF deverão possuir os seguintes aspectos básicos: ter duração de, no máximo, dois dias; bem como estar voltados à atividades turísticas alternativas, de preferência relacionadas ao ecoturismo, podendo aproveitar, inclusive, o potencial turístico da Região do Entorno do DF.

Frente ao até então exposto tem-se que, após terem sido descritos os dados e as respectivas análises acerca da pesquisa de campo, passa-se, no próximo capítulo, a expor a proposta de roteiro turístico voltado a pequenos grupos de visitantes que, estando em Brasília, buscam programação alternativa, relacionada a turismo ecológico. 


\section{PROPOSTA}

Conforme RUSCHMANN ${ }^{129}$, dentro do enfoque de que o marketing é um conceito voltado para o consumidor, os componentes do produto turístico devem ser examinados sob o ponto de vista dele. Par ao turista, o produto engloba a experiência completa, desde o momento que sai de casa para viajar, até o retorno. Assim, essa autora afiram que o produto turístico é:

"a amálgama de elementos tangíveis e intangíveis, centralizada em uma atividade específica e em uma determinada destinação e as formas de acesso das quais o turista compra a combinação de atividades e arranjos" ${ }^{\prime 30}$.

Em uma outra definição, RUSCHMANN (1991) completa essa definição, afirmando que:

"o produto turístico como um pacote turístico que inclui as atrações, as facilidades, os transportes etc., e, assim, todos os turistas compram pacotes, quando viajam por intermédio de uma agência ou não"131.

Essa visão apresentada acima por RUSCHMANN (1991) é a que se adota neste trabalho, em que os pacotes turísticos oferecidos aos turistas se baseará na combinação de arranjos e atividades, como oportunidade de promover o ecoturismo na capital federal e na região do entorno.

A análise dos resultados será feita com base em levantamento "in loco”, após o qual, por meio da utilização da estatística como instrumento de comparação, se mensurará a opinião de profissionais da área, a respeito da possibilidade de se inserir, no mercado de Brasília, um roteiro ecoturístico individual ou em pequenos grupos (de até, no máximo, 4 pessoas), para, ao final, com os resultados, combinados com a bibliografia consultada apresentar um roteiro ecoturístico na região do entorno de

\footnotetext{
${ }^{129}$ RUSCHMANN, Doris. Turismo e planejamento sustentável: a proteção do meio ambiente. 8. ed. Campinas (SP): Papirus, 1997, p. 26.

${ }^{130}$ Idem, ibidem.

${ }^{131}$ Idem, ibidem.
} 
Brasília direcionado para um determinado público do mercado que tenha disponibilidade por curto prazo. Sendo assim, os roteiros ecoturísticos oferecidos podem ser assim descritos:

a) Passeio de $1 \frac{1}{2}$ dia (de até $50 \mathrm{~km}$ de Brasília, sem pernoite):

- Cachoeira do Tororó - 35km de Brasília;

- Cachoeira do Poço Azul - 5km de Brasília;

- Cachoeira da Saia Velha - 35km de Brasília;

- Cachoeira do Girassol - 21km de Brasília;

- Chapada Imperial - 50km de Brasília;

- Mumunhas - 44km de Brasília;

- Parque Nacional de Brasília; ou,

- Jardim Botânico de Brasília.

b) Passeio de 1 dia (de até 150km de Brasília, sem pernoite):

- Cachoeira do Arrojado - 134km de Brasília;

- Salto do Itiquira - 110km de Brasília;

- Linda Serra dos Topázios - 100km de Brasília; ou,

- Cachoeira do Rio do Sal - 68km de Brasília.

c) Passeio de 1⁄1/2 ou 2 dias (acima de $150 \mathrm{~km}$ de Brasília, com pernoite):

- Pirinópolis - 150km de Brasília;

- $\quad$ Alto Paraíso - 230km de Brasília;

- São Jorge - 266km de Brasília;

- Cidade do Goiás - 320km de Brasília; ou,

- Cavalcante - 330km de Brasília.

Primeiro é preciso informar que os preços não foram informados, em face da necessidade de constantes reajustes, ou mesmo das opções de trajeto escolhidas pelos turistas. Dito isso, deve-se esclarecer que, os tipos de passeio de ecoturismo podem ser combinadas com as modalidades de turismo místico-religioso e turismo arquitetônico (segmentos turísticos importantes, conforme a localidade, como é o caso, por exemplo, 
de Pirenópolis, Alto Paraíso e da própria Brasília).

Contudo, os passeios do tipo “a” (1/2 dia), em face do reduzido espaço de tempo conferido ao turista, não poderá ser combinada com outras modalidades turísticas, ficando as combinações restritas apenas aos tipos “b” e “c”, respectivamente, 1 dia 1 1⁄2 dia e 2 dias, quando ao turista será ofertado maior tempo de duração do passeio.

Quando o roteiro estiver direcionado a uma cidade, ao chegar ao destino, fica a critério do turista contratante realizar, ou não, outras visitas aos atrativos naquela comunidade. Com isso, pretende-se dar maior liberdade a grupos de turistas (de, no máximo, 4 pessoas), inclusive, não confrontando os empreendimentos locais, tais como guias turísticos e propriedades particulares (mesmo porque, essa atividade, “com guia de viagem”, já é oferecida no mercado). Dessa forma, a intenção do roteiro é facilitar o deslocamento de pequenos grupos, sem, no entanto, afetar as estruturas de negócios já existentes nas cidades visitadas.

Ainda sobre os roteiros deve-se esclarecer que, a inexistência de roteiros minuciosamente pré-determinados (com horários fixos e trajetos específicos) foi proposital, visando-se, com isso, dar maior liberdade aos pequenos grupos (de, no máximo, 4 pessoas), os quais ficam livres para escolher horários e trajetos. Aqui, lembra-se também que não se trata de "city tour", mas de um projeto cujo objetivo maior seja a divulgação do ecoturismo no DF e sua Região do Entorno.

Os passeios aqui propostos são diferente (e até mesmo opostos) aos que normalmente são comercializados na cidade, visto que se trata de uma opção de caráter ecológico, “alternativa” ao passeios nos quais os turistas querem apenas conhecer os pontos turísticos convencionais da Capital (Torre de Televisão, Catedral, Esplanada dos Ministérios, entre outros).

A razão principal pela qual não se impõe aos turistas quaisquer passeios relacionados a empreendimentos já existentes nas comunidades visitadas, dá-se em razão de que isso se constituiria no que se chama de "venda casada", atitude 
expressamente proibida pelo Código de Defesa do Consumidor, ficando totalmente a critério dos turistas quais roteiros de ecoturismo gostariam de 'combinar' ('casar’) com as opções aqui oferecidas (turismo arquitetônico, turismo místico-religioso e outros).

Além disso, as opções de passeio aqui propostas têm, como principal relação com Brasília e sua Região do Entorno, o fato de abrangerem locais que oferecem atrativos turísticos naturais (bem preservados), diferentes do que há somente na Capital. Não obstante, esses grandes atrativos, quase todos fora do perímetro do Distrito Federal, têm em Brasília, no entanto, seu ponto inicial de chegada e de partida (seja em via terrestre ou aérea). Daí a importância de se desenvolver o ecoturismo na mencionada Região.

Note-se que são pacotes de curta duração, direcionados aos turistas que dispõem de pouco tempo livre, conforme revelado na pesquisa de campo. Cabe esclarecer que os roteiros acima apresentados também podem ser combinados com os empreendimentos denominados "turismo rural” (hotéis fazenda, fazendas, pesque-pagues, clubes etc.), bastando, para tanto, que o contratante aceite, quando for o caso, o acréscimo dos valores cobrados pelo empreendimento adicionado ao roteiro.

Esses roteiros derivaram da experiência deste estudante como funcionário de hotéis em Brasília, por aproximadamente 2 anos, quando ocupou os cargos de recepcionista e de supervisor de recepção, período este que presenciou, inúmeras vezes, a pergunta feita por hóspedes que, estando sozinhos ou em grupos de no máximo 4 pessoas, já tendo lido ou ouvido falar da região e, ainda, dispondo de pouco tempo livre: “- Fora do convencional, de preferência relacionado à natureza, o que posso fazer em Brasília em termos de lazer?”. Daí dizer-se que os roteiros já apresentados buscam ser uma resposta a esse questionamento.

Para finalizar este capítulo, necessário se faz ressaltar que, mesmo não estando diretamente relacionados com as atrações específicas de cada localidade visitada, ainda assim os passeios aqui propostos podem levar a diversos desdobramentos, por forças das possibilidades que os turistas terão de fazerem escaladas, tomarem banhos em rios e 
cachoeiras, conhecerem vegetação exótica, entre outros tantos atrativos. Essas variações podem ser aproveitadas, ao longo do tempo, como elementos de marketing dos próprios roteiros. Daí entender-se também que, desde o princípio, ao fazer a viagem de volta, o ideal é que se aplique um pequeno questionário junto aos turistas, de modo a coletar informações sobre as regiões visitadas, permitindo a estruturação de um banco de dados, o qual poderá, como já se disse, ser de fundamental importância para a formulação de campanhas de divulgação, bem como para futuras tomadas de decisão a respeito da evolução do negócio.

Assim, após a apresentação das propostas, passa-se agora, no próximo capítulo, a expor as conclusões gerais deste trabalho. 


\section{CONCLUSÕES}

Quando se fala em ecoturismo, a idéia essencial que se deve ter em mente é a de que, como negócio, esta modalidade de empreendimento é, de certa forma, uma antítese à maioria das demais organizações capitalistas ocidentais. Não porque deixa de ver no lucro um objetivo a perseguir, mas sim porque deixa de ver esse mesmo lucro como o principal objetivo.

Nos empreendimentos ecoturísticos, a idéia mais importante é a de sustentabilidade, ou seja, a de garantir (ou pelo menos se esforçar para tanto) que o meio ambiente não será significativamente degradado em decorrência dos negócios ali constituídos. Afinal, para esse estudo foi adotado o conceito exposto por MOLINA ${ }^{132}$, para o qual, “o esforço de sustentabilidade é promovido para melhorar a qualidade da vida humana, sem ultrapassar a capacidade de sustentação dos ecossistemas que a mantém”.

Em ecoturismo, a noção de produção e consumo de bem ou serviço é acrescida da idéia de continuidade, de não devastação, de compromisso para com as gerações futuras, ou seja, de "sustentabilidade”. Sendo assim, quando se fala em “desenvolver o ecoturismo”, o que se quer dizer é “desenvolver os ideais de ecoturismo”, propagá-los, torná-los noção de valor aceita de modo generalizado e na forma de sério compromisso. Por isso mesmo, buscou-se conhecer como agiam e pensavam os autores que versam sobre ecoturismo.

No trabalho aqui apresentado, tentou-se mostrar que é possível desenvolver empreendimento ecoturístico de modo segmentado. Com isso, o negócio é estruturado para atender a públicos específicos, de pequeno porte, cuja possibilidade de danos ao meio ambiente e às culturas visitadas se reduz consideravelmente.

No que tange às questões-problema inicialmente levantadas, tem-se que as mesmas podem ser assim entendidas:

${ }^{132}$ MOLINA, Sérgio. Turismo e ecologia. Bauru (SP): EDUSC, 2001, p. 182. 
A primeira questão-problema foi assim apresentada: o mercado turístico de Brasília comporta inovações, tais como as modalidades mais modernas de turismo (turismo de aventura, turismo ecológico, entre outros), ou é, em sua maior parte, um mercado conservador (turismo de eventos, turismo de lazer), ou seja, aquele em que predomina o consumo dos produtos tradicionais (tais como turismo de negócios ou de eventos)? Sim, o mercado turístico de Brasília comporta inovações, tais como as modalidades mais modernas de turismo (turismo de aventura, turismo ecológico, entre outros). Conforme mostrou a pesquisa, há campo para exploração de atividades alternativas, desde que sejam de curta duração, posto que, em sua maioria, as pessoas que visitam Brasília o fazem por breve espaço de tempo, raramente ultrapassando a dois dias.

Por sua vez, a segunda questão-problema foi assim estruturada: há, em Brasília, um público significativo (22\% da amostra) para um roteiro ecoturístico voltado para o consumidor individual, ou de pequenos grupos (de, no máximo, quatro pessoas), e que tenham pouca disponibilidade de tempo? Ou, ainda: que tipo de demanda esse público almeja? Sobre isso, a pesquisa revelou que há esse público.

Contudo, não se pode dizer que o mesmo seja significativo, considerando-se que as organizações pesquisadas não dispõem de números precisos quanto a isso. Entretanto, por se tratar de atividades alternativas, entende-se que os programas turísticos a serem oferecido a esses visitantes poderão, por se tratar de serviço especial, ter preço mais elevado que as atividades turísticas convencionais, o que, em tese, deverá compensar o fato de que esses turistas não chegam a ser numericamente volumosos.

Já a terceira questão-problema assim indagava: é possível combinar, a inserção, no mercado de Brasília ou na região do entorno, de um roteiro ecoturístico de curta duração (de no máximo dois dias) voltado ao consumidor individual ou de pequenos grupos, que, ao mesmo tempo, não se converta em ação devastadora do patrimônio e do ecossistema locais, mas que, ao contrário, se converta em compromisso de desenvolvimento sustentável, em que se busque a preservação do meio ambiente? Em verdade, a pesquisa, embora permita afirmar que é possível a inserção de tais roteiros no 
Distrito Federal e na Região do Entorno, não pode garantir que não haverá danos ao meio ambiente, o que somente seria possível verificar por meio de projetos-piloto, frente aos quais se poderia, inclusive, apresentar sugestões de correção das possíveis disfunções apresentadas.

Com isso, a pretensão maior é, além de dinamizar o turismo e a economia das comunidades visitadas, promover o ecoturismo no Distrito Federal, tornando, de forma sustentável, mais conhecidos seus principais pontos de atração, combinando as modalidades, tais como o ecoturismo com turismo místico-religioso ou turismo arquitetônico, aproveitando, assim, o potencial de Brasília e do Entorno.

Assim, tendo sido atingido os objetivos inicialmente propostos, afirma-se que este estudo não teve a intenção de esgotar o assunto, cuja complexidade permite que o mesmo seja retomado em outras oportunidades, quando, inclusive, deverá ser considerado um rol maior de variáveis, de modo a propiciar maior entendimento sobre o tema. 


\section{REFERÊNCIAS BIBLIOGRÁFICAS}

ALBUQUERQUE, Heloísa M. C. de. “Instruções para elaboração de projetos, monografias e relatórios”. Brasília: Universidade Católica de Brasília, 1992.

ANDRADE, José V. Turismo - fundamentos e dimensões. São Paulo: Ática, 1992.

BARRETO, Margarita. Manual de iniciação ao estudo do turismo. Campinas (SP): Papirus, 1995.

BARROSO, L. R. O direito constitucional e a efetividade de suas normas: limites e possibilidades da constituição brasileira. Rio de Janeiro: Renovar, 1996.

BOBBIO, N. O futuro da democracia: uma defesa das regras do jogo. 3. ed. Rio de Janeiro: Paz e Terra, 1987.

BOO, E. O planejamento ecotursítico para áreas protegidas. São Paulo: SENAC, 1998.

CAPPELLETTI, M. Acesso à justiça. Porto Alegre: Sérgio Antônio Fabris Editor, 1988

CEBALLOS- LASCURAIN, Hector. Ecoturismo. México: Diana, 1987.

CMMAD, Comissão Mundial sobre Meio Ambiente e Desenvolvimento. Nosso furuto comum. 2. ed. Rio de Janeiro: Fundação Getúlio Vargas, 1988.

CORIOLANO, Luzia. O ecoturismo e os hóspedes da natureza. <http://www.redebonja.cbj.g12.br> Acesso em: 15.jun. 2003.

COSTA, Patrícia Côrtes. Ecoturismo. São Paulo: Aleph, 2002.

CRESPO, Samyra. Desenvolvimento sustentável: as ONG's devem se engajar na elaboração das Agendas 21. Revista trimestral de debate da fase. Ano 27 nº 77 . Ed. 
Fase, 1998.

DENCKER, Ada de Freitas. Métodos e técnicas de pesquisa em turismo. São Paulo: Futura, 1998.

DIAS, G. Freire. Educação ambiental: princípios e práticas. São Paulo: Gaia, 1992.

EMBRATUR. Diretrizes para uma política nacional de ecoturismo. Brasília: EMBRATUR, 1994.

EMBRATUR. “Inventário da oferta turística”. Brasília: Embratur, 2004.

EMBRATUR. Programa ecoturismo: versão preliminar. Brasília: EMBRATUR, 1991.

EMBRATUR. “Projeções econômicas para o turismo brasileiro. Brasília: UnB, 2002.

FERREIRA FILHO, M. G. Poder Judiciário na Constituição de 1988 - Judicialização da Política e Politização da Justiça, in: Revista de Direito Administrativo, n. ${ }^{\circ}$ 198, Rio de Janeiro: 1994.

FIGUEIREDO, G. J. P. de. Reengenharia do Estado: a Procuradoria-Geral do Estado e a Polícia Florestal na Proteção do Meio Ambiente. Boletim do Instituto Brasileiro de Advocacia Pública, ano III, n. ${ }^{\circ}$ 5, junho 1997.

FIGUEIREDO, Luiz A. V. Ecoturismo e participação popular no manejo de áreas protegidas: aspectos conceituais, educativos e reflexões. São Paulo: Hucitec, 1997.

FREITAS, V. P. (Org.). Direito ambiental em evolução. Curitiba: Juruá, 1998.

GOLDENBERG. Mirian. “A arte de pesquisar”. 2. ed. São Paulo: Record, 1997. GOMES, P. (Eco)turismo: uma (re)leitura dos discursos. Brasília, 2000. Brasília: UnB, 2000. 
GUEERA, I. F. A efetividade do direito ambiental, in: Revista do Instituto Brasileiro de Advocacia Pública, n. ${ }^{\circ}$ 2. São Paulo: Max Limonad, 1998.

KRIPPENDORF, Jost. Sociologia do turismo - para uma nova compreensão do lazer das viagens. Rio de Janeiro: Civilização Brasileira, 1989.

LAGE, Beatriz Helena Gelas., MILONE, Paulo César. Turismo - teoria e prática. São Paulo: Atlas, 2000.

LEMOS, Amália (Org). Turismo: impactos sócio-ambientais. São Paulo: Hucitec, 2001.

LINDBERG, Kreg \& HAWKINS, Donald E. Ecoturismo - um guia para planejamento e gestão. 4. ed. São Paulo: SENAC, 2002.

MACEDO, R. K. Gestão ambiental de territórios - os instrumentos básicos para a gestão ambiental de territórios e unidades produtivas. Rio de Janeiro: ABES, AIDIS, 1994.

MACHADO, P. A. L. Direito ambiental brasileiro. São Paulo: RT, 1999.

MIRRA, A. L. V. Fundamento do direito ambiental no Brasil, in: RT, n. ${ }^{\circ}$ 706, agosto de 1994.

MOLINA, Sérgio. Turismo e ecologia. Bauru (SP): EDUSC, 2001.

NUNES, Brasilmar Ferreira. “Brasília: a fantasia corporificada”. Brasília: Paralelo 15, 2004.

OCE, Oficinas de Capacitação em Ecoturismo. Disponível em: < http//www.ecosfera.com.br>. Acesso em: 15 jul. 2003.

OLIVEIRA, A. Turismo e desenvolvimento. Florianópolis (SC): Terceiro Milênio, 
1998.

OMT, Organização Mundial de Turismo. Dados e tendências mundiais. <http://www.world-tourism.org>. Acesso em 05.set.2003.

OCTAVIAN, Rosiu Ovidiu Petra; PAULESCU, Doina; MUNIZ, Adir Jaime de Oliveira. Normas para apresentação do relatório final do estágio profissional curricular supervisionado - EPCS. Brasília: UniCEUB, 2002.

PELLEGRINI FILHO, A. Ecologia, cultura e turismo. Campinas (SP): Papirus, 1993.

PERELMAN, C. Ética e direito. São Paulo: Martins Fontes, 1996.

PINTO, A. C. B. Turismo e meio ambiente: aspectos jurídicos. Campinas: Papirus, 1998.

PIRES, P. S. A dimensão conceitual do ecoturismo. São Paulo: Atlas, 1998.

REIGOTA, M. O que é educação ambiental. Coleção Primeiros Passos. São Paulo: Brasiliense, 1994.

RUSCHMANN, Doris. Turismo e meio ambiente. Campinas: Papirus, 1990.

RUSCHMANN, Doris. Turismo e planejamento sustentável: a proteção do meio ambiente. 8. ed. Campinas (SP): Papirus, 1997.

SERRANO, Célia M. (Org.). A educação pelas pedras - ecoturismo e educação ambiental. São Paulo: Chronos, 2000.

SERRANO, Célia M. Toledo \& BRUHNS, Heloísa T. (Orgs.). Viagens à natureza turismo, cultura e ambiente. Campinas (SP): Papirus, 1997. 
SETUR-DF. “Guia de visitações”. Brasília: SETUR, 2003.

SIQUEIRA, Deis \& LIMA Ricardo Barbosa de. "Sociologia das adesões: novas religiosidades e a busca místico-exotérica na capital do Brasil”. Rio de Janeiro: Garamond Vieira, 2003.

SPONHOLZ, O. L. Meio ambiente - dano e responsabilidade civil. São Paulo: RT, 2000.

SWARBROOKE, John. Turismo sustentável, turismo cultural, ecoturismo e ética. São Paulo: Aleph, 2000.

TOURINHO NETO, F. C. Dano ambiental, in: Revista Consulex, n. ${ }^{\circ}$ 2, ano 1, Fevereiro de 1997.

TRIGO, Luis Gonzaga Godoi. Turismo básico. São Paulo: SENAC, 1995.

TRIGO, Luiz Gonzaga Godoi. Turismo e qualidade - tendências contemporâneas. Campinas (SP): Papirus, 1993.

WALCACER, F. C. Meio ambiente urbano no Brasil. São Paulo: RT, 1993.

WESTERN, David. Definindo ecoturismo. São Paulo, 1999.

VERGARA, Sylvia Constant. Projetos e relatórios de pesquisa em administração. 2. ed. São Paulo: Atlas, 1998.

VIEGAS, Waldyr. Fundamentos de metodologia científica. Brasília: Universidade de Brasília, 2000. 


\section{INTERNET:}

http://www.mma.gov.br (acesso em 04.09.2003, às 22:15).

http://www.candango.com.br (acesso em 04.09.2003, às 23:18).

http://www.trt10.gov.br/default/jurisp/BIEJ1_00.htm.

http://www.viaecologica.com.br/brasilia.jpg (acesso em 26.06.2004). 
ANEXOS 


\section{Anexo I - Pré-teste}

Prezado respondente, após preencher o formulário anexo, solicito a gentileza de responder as perguntas abaixo, pelo que antecipadamente agradeço.

01 Alguma das questões pode causar constrangimento?
(a) Sim.
(b) Não.

Quais?

02. Alguma das questões lhe parece de difícil entendimento?
(a) Sim.
(b) Não.

Quais?

03. Alguma das questões lhe parece tendenciosa?
(a) Sim.
(b) Não.

Quais?

04. Alguma das questões lhe parece redundante ou dispensável?
(a) Sim.
(b) Não.

Quais?

05. O formulário é de fácil preenchimento?
(a) Sim.
(b) Não.

Quais?

06. A quantidade de questões lhe parece excessiva?
(a) Sim.
(b) Não.

Quais? 


\section{Anexo II - Questionário}

Prezado respondente, após preencher o formulário anexo, solicito a gentileza de responder as perguntas abaixo, pelo que antecipadamente agradeço.

01. É freqüente, neste estabelecimento, hóspedes que permanecem em Brasília por prazo igual ou inferior a 2 dias?
(a) Sim.
(b) Não.

02. É freqüente, entre os hóspedes, alguém perguntar sobre a existência de programação turística alternativa?
(a) Sim.
(b) Não.

03. É freqüente, entre os hóspedes, alguém indagar sobre a existência de programação turística de curto prazo (de, no máximo, 2 dias)?
(a) Sim.
(b) Não.

04. É freqüente, entre os hóspedes, alguém indagar sobre a existência de programação turística voltada para atividades ecológicas?
(a) Sim.
(b) Não.

05. É freqüente, entre os hóspedes, visitantes, desejando desfrutar de atividades turísticas relacionadas à Região do Entorno do Distrito Federal?
(a) Sim.
(b) Não. 